\title{
Chapter 5 \\ The Legal Structure of Competition Policy in Turkey
}

\author{
Kerem Cem Sanli and Sahin Ardiyok*
}

\subsection{Introduction}

In the last 20 years, states across the globe have relied increasingly on market economy as a way of allocating resources, in the hope that markets would produce the most desirable outcomes. However, to attain these outcomes, markets require a strong and solid legal framework. Antitrust laws are considered to be the main components of this legal framework.

As Turkey has been implementing market system for the past 20 years, the national laws regulating trade and economy have been steadily altered, and new laws have been enacted to cope with the dynamics of this system. The Act of Protection of Competition, which was adopted in 1994, can be regarded as a product of the process of forming the legal framework. By enacting the Act, Turkish government endorsed "competition" as a social value and also fulfilled its legal obligations stemming from the Constitutional mandate (art. 167) and the acquis of the European Union.

Despite having some unique provisions, the Act is modeled on European competition law (the art. 101-102 of the Rome Treaty), which renders the judgments and the policies of the European authorities very relevant to Turkish practice. The Act established the Competition Authority as the main enforcement body equipped

\footnotetext{
*Former official of Turkish Competition Authority, present partner of ACTECON Economic Consulting, and lecturer of "Economic Regulation and Law," "Telecommunications Law," "Energy Law and Policy," and "Pharmaceutical Law" at Istanbul Bilgi and Ankara Bilkent Universities. Special thanks to ACTECON partners and all consultants for their contribution to this study.

S. Ardiyok $(\bowtie)$

Actecon Economic Consultancy, Istanbul, Turkey

and

The School of Law, Bilgi University, Istanbul, Turkey

and

The School of Law, Bilkent University, Ankara, Turkey

e-mail: sahin.ardiyok@actecon.com

K.C. Sanli

Assistant Professor and Director of the Competition Law and Policy Research Center at Istanbul Bilgi University Faculty of Law and Adjunct Professor at Bilkent University LL.M. Program
} 
with executive as well as rule-making powers. For the past 13 years, the Authority and the Board, the decision-making body, have been very active, especially with respect to legislative functions.

The purpose of this study is to introduce readers to the basics of Turkish Antitrust Law and its enforcement practices. In this respect, the chapter is categorized into four parts. The first part covers the background and the sources of the Turkish Antitrust Law. After the legislative background is mentioned, the main legal sources of the law are specified. The second part is devoted to the main concepts prescribed in the Act such as the relevant market and the concept of undertaking. Substantive provisions are explained in the third part, and this part is organized under three headings. First, restrictive agreements are expounded along with the exemption rule. Subsequently, the abuse of dominant position is illustrated with some examples of abuse. And finally, the provision and the secondary legislation governing the concentrations are explained. Here, the procedural issues are of importance. Enforcement authorities and sanctions are discussed in the final part.

\subsection{Background and the Sources of the Antitrust Law}

The main legal source of the Turkish Antitrust Law is the Act on the Protection of Competition numbered 4054 (herein referred to as the Antitrust Act). ${ }^{1}$ The Antitrust Act was enacted in 1994, and prior to this date, Turkey did not have an antitrust legislation despite the legal mandate in the Article 167 of the Turkish Constitution dated 1982, which obliges the government to prevent cartelization and monopolization in the economy. ${ }^{2}$ However, it should be mentioned that there were several attempts to make antitrust legislation in the late-1970s and early-1980s, but the drafts that were prepared upon these initiatives were not finalized in the legislative process. So, the Antitrust Act, which was drafted during the years 1992-1994, filled an important loophole in the Turkish legal system.

Because of the late establishment of the Competition Authority, the main enforcement body vested with investigative and rule-making powers, the effective enforcement of the Antitrust Act was initiated in 1997, 3 years after the adoption of the Act. ${ }^{3}$ Since then, it has been subjected to several amendments, ${ }^{4}$ which mainly aimed at strengthening and rationalizing the operational efficiency of the Competition

\footnotetext{
${ }^{1}$ The Act on the Protection of Competition No: 4054. Date of Adoption: 7/12/1994. OG. Date: 13/12/1994, Number: 22140.

${ }^{2}$ The first paragraph of the Article 167 provides that "the state shall take measures to ensure and promote the sound, orderly functioning money, credit, capital, goods and services markets; and shall prevent the formation, in practice or by agreement, of monopolies and cartels in the markets."

${ }^{3}$ The Communique on the Conclusion of the Organization of the Competition Authority, No: 1997/5 OG. Date: 9.12.1998, Number: 23461.

${ }^{4}$ The Acts that have amended the Antitrust Act can be listed as follows: the Act numbered 4971, dated 01.08.2003; the Act numbered 5234, dated 17.9.2004; the Act numbered 5388, dated 2.7.2005, and the Act numbered 5728, dated 23.1.2008.
} 
Authority and the enforcement system. Substantive rules have been intact since the enactment of the Antitrust Act.

Most of the 63 provisions of the Antitrust Act are related to the institutional structure and legal powers of the Competition Authority. Few substantive rules are found in section 2 between Articles 4 and 7 and in section 5 between Articles 56 and 59. When one considers the nature of these rules, it is easily observed that the Antitrust Act is modeled on the European Community Antitrust Law (herein referred to as European Antitrust Law). In particular, substantive rules prohibiting restrictive agreements and abuse of dominant position are almost identical to the Articles 101 and 102 of the TFEU. This is a natural consequence of the fact that Turkey has an obligation to harmonize its laws with those of the European Union. Hence, the Turkish Antitrust Law including secondary legislation is congruent with the European Antitrust law.

The secondary legislation consisting of regulations, communiqués and guidelines, and the Turkish Competition Board Decisions are other sources of the Antitrust Law. Among these resources, probably the most important ones are block exemption communiqués, given the extensive coverage of these rules. The Turkish Competition Board has issued various block exemption communiqués, which are based on European Antitrust Law, covering vertical restraints, ${ }^{5}$ insurance sector, ${ }^{6} \mathrm{R}$ \& D agreements, ${ }^{7}$ and technology transfer agreements. ${ }^{8}$ Merger Communiqué, numbered $1997 / 1,{ }^{9}$ which lays down principles of merger analysis, has an important function in merger control. Also, to strengthen the cartel enforcement policy, two regulations have recently been enacted, one being the Leniency ${ }^{10}$ and the other being the Fine Regulation, ${ }^{11}$ and these regulations have become vital in enforcement practice. The vagueness of the substantive provisions of the Antitrust Act amplifies the importance of these legal sources. In particular, the decisions of the Turkish Competition Board, the decision-making body of the Competition Authority, provide useful guidance in the interpretation of the Antitrust Act, which is unique for the Turkish legal system given that the Turkish Competition Board is not a judiciary organ.

Apart from these legal sources, there are various provisions in other Acts that also aim at protection of competition. These provisions are mainly found in the

\footnotetext{
${ }^{5}$ The Block Exemption Communiqué on Vertical Agreements, No: 2002/2, OG. Date: 7.14.2002, Number: 24815.

${ }^{6}$ The Block Exemption Communiqué in Relation to Insurance Sector, No: 2008/3, OG. Date: 2.1.2008, Number: 26774.

${ }^{7}$ The Block Exemption Communiqué on Research and Development Agreements, No: 2003/2, OG. Date: 8.27.2003, Number: 25212.

${ }^{8}$ The Block Exemption Communiqué on Technology Transfer Agreements, No: 2008/2, OG. Date: 1.23.2008, Number: 26765.

${ }^{9}$ The Communiqué on the Mergers and Acquisitions, No: 1997/1, OG. Date: 8.12.1997, Number: 23078.

${ }^{10}$ The Regulation on Active Cooperation for Detecting Cartels, OG. Date: 15.2.2009, Number: 27142 .

${ }^{11}$ The Regulation on Fines to Apply in Cases of Agreements, Concerted Practices, and Decisions Limiting Competition and Abuse of Dominant Position, OG. Date: 15.2.2009, Number: 27142.
} 
Acts regulating special industries such as banking, energy, and telecommunication. Therefore, they cannot be qualified as antitrust law. Also, there are few provisions in the Criminal Code that can be concurrently applied to an antitrust infringement. For example, Article 235 of the Turkish Criminal Code prohibits collusive practices in public bids. Arguably, the first paragraph of Article 237 can also be applied against price-fixing cartels.

\subsection{Main Concepts}

The Turkish Antitrust Law deals with three major problems, which may endanger the functioning of the market economy. Rules remedying these problems consist of (a) the prohibition of agreements, concerted practices, and decisions regarding firms restricting competition (Article 4), (b) the prohibition of abuse of dominant position (Article 6), and (c) mergers and acquisitions (Article 7).

The Competition Board is the sole administrative body that can apply these rules to undertakings covered by the scope of the Antitrust Act. In each of these rules, there are three main points that the Turkish Competition Board takes into consideration:

- The relevant market, including both product and geographical markets in which the undertaking operates

- Territorial reach, which determines whether the geography of the activity is caught by the Antitrust Act

- Exemptions related to the industry that the undertaking in question falls under

Below, the applicability of the Antitrust Act is examined in terms of relevant markets, territorial reach, and special industries.

\subsubsection{Scope of Application}

The scope of the Antitrust Act is set forth in Article 2. Basically, the provision describes the dimensions of application in terms of the transactions between undertakings, geographic territory, and effects of the transactions on competition. Article 2 provides a clear explanation as follows:

Agreements, decisions and practices which prevent, distort, or restrict competition between any undertakings operating in or affecting markets for goods and services within the boundaries of the Republic of Turkey, and the abuse of dominance by the undertakings dominant in the market, and any kind of legal transactions and behavior having the nature of mergers and acquisitions which shall decrease competition to a significant extent, and transactions related to the measures, establishments, regulations and supervisions aimed at the protection of competition fall under this Act. 
Under further subtitles, the scope is observed in detail by elucidating the method of defining the relevant market, the Antitrust Act's territorial reach, and special industries that are subject to special rules or not subject to the Antitrust Act.

\title{
5.3.1.1 Relevant Market
}

The purpose of defining the relevant market is to identify which products and services are close substitutes for one another so that they operate as a competitive constraint on the behavior of the suppliers of those products or services (Jones and Sufrin 2004, p. 48). Thus, to decide whether there is an anticompetitive conduct in the market, defining the market is the priority subject on the to-do list of the Turkish Competition Board.

Although the definition of the relevant market does not appear explicitly in the Antitrust Act, a clause containing product and geographical market definitions was set forth in the previous Merger Communiqué. The Article 4 of the previous Merger Communiqué states the following:

\begin{abstract}
The geographic market which comprises a substantial part of the country within the meaning of paragraph 1, are areas in which undertakings operate in the supply and demand of their goods and services, in which the conditions of competition are sufficiently homogenous, and which can easily be distinguished from neighboring areas, as the conditions of competition are appreciably different from these areas.

In determining the relevant product market within the meaning of paragraph 1 , the market comprising the goods or services which are the subject of a merger or an acquisition, and the goods or services which are deemed identical in the eye of consumers in terms of their prices, intended use and characteristics is taken into account; other factors that may affect the market determined shall also be assessed.
\end{abstract}

Moreover, there is a Guideline ${ }^{12}$ enacted by the Turkish Competition Board to provide a framework based on economic principles. This Guideline is aimed at ascertaining which competitors have the power to restrict the behavior of the undertakings under examination, and preventing these from behaving independently of an efficient competitive pressure. This guideline explains technically the methods and objective criteria that the Turkish Competition Board applies in its decisions.

In its many decisions, the Turkish Competition Board follows the rules set by the Guideline. The Guideline lists the basic principles of market definition as demand substitution, supply substitution, and potential competition. Demand substitution, determining other products that consumers deem substitutable for the relevant product, and supply substitution, where suppliers could be able to switch their production to other products when faced with small and nontransitory increases in relative prices, are the main consideration points for the Turkish Competition Board. As an instance, in its case dated 25.9.2008 and numbered

\footnotetext{
${ }^{12}$ Guidelines on the Definition of Relevant Market (http://www.rekabet.gov.tr/dosyalar/kilavuz/ kilavuz5.pdf).
} 
08-56/891-352, in which a fruit yogurt license agreement was signed between Pinar and Sodima SAS, the Turkish Competition Board compared yogurt types, namely, fruit yogurt and fruit cheese to determine the relevant product market. The Turkish Competition Board observed that these are not substitutes to each other in either demand or supply level while stating the reasons as follows:

Therefore fruit cheese is not a substitute to fruit yogurt regarding its consumer group (mostly children) in terms of demand. Moreover, from the supply substitution point, any yogurt producer cannot easily produce fruit cheese, similar to fruit yogurt, depending on its additional investment and know-how requirements.

In the course of the assessment on defining the relevant market by either the Turkish Competition Board or the European Commission, a three-dimensional method consisting of the "product market," "geographical market," and "temporal market" is generally used (Sanl1 2000a, p. 246). However, "temporal market" dimension is stated neither in the Merger Communiqué nor in the Guideline published by the Turkish Competition Board, while it can be considered in several cases depending on its relevance with time. ${ }^{13}$

Many of the Turkish Competition Board decisions involve market definitions, determination of both the product market and geographical market. The Turkish Competition Board defines market especially in application of Article 6, abuse of dominant position, and Article 7, mergers and acquisitions, as these provisions require a given market.

\subsubsection{Territorial Reach}

As mentioned in the Article 2 of the Antitrust Act regarding scope, the Act covers "agreements, decisions and practices which prevent, distort or restrict competition between any undertakings operating in or affecting markets for goods and services within the boundaries of the Republic of Turkey."

In accordance with this rule, an anticompetitive practice exercised by an undertaking within the boundaries of Turkey or an undertaking operating or residing in Turkey will not make any difference in terms of the application of the Antitrust Act. What matters is whether the outcomes of the conduct exercised by the undertaking residing in Turkey or in abroad negatively affect the competition in a Turkish market. This rule holds the undertakings that reside or operate abroad liable for their conduct if they infringe competition rules in Turkey (Sanl 2000a, p. 246).

Scholars have named this approach as "effects doctrine," a common principle stating that competition rules shall be applied to any undertaking, irrespective of its nationality or residence, upon the effects of its practices or transactions on the

\footnotetext{
${ }^{13}$ In the 25.8.2009 dated and 09-38/925-218 numbered decision of the Turkish Competition Board, the Board stated that beer sales should display the differences upon the winter and summer seasons, and, therefore, this factor should be taken into account while considering the dominant position in the relevant market.
} 
competition conditions in that country. ${ }^{14}$ The resulting effect within domestic territory is the sole condition for the application of this doctrine, ${ }^{15}$ and even its negative or positive feature is no matter (Erol 2000, p. 161). The "effects doctrine" was embraced by the Court of First Instance in the Gencor Case when stating that the application of the Merger Regulation to a merger between companies located outside EU territory "is justified under public international law when it is foreseeable that a proposed concentration will have an immediate and substantial effect in the Community."

When it is considered that the object of the Antitrust Act is the protection of competition in the markets within domestic territory, then it should be admitted that any restrictive behavior affecting the Turkish market, irrespective of where it is realized, shall be sanctioned in the scope of the Antitrust Act.

\subsubsection{Special Industries}

Normally, the Antitrust Act covers all portions of the economy. Exceptionally, there are some special industries that have some permanent market failures and thus require special provisions to correct them by regulation. This portion of the economy is normally out of the scope of the Antitrust Act. There are some other industries without serious market failures but immune from the application of Antitrust Law.

In EU, until 2002 coal and steel industries were governed by the European Coal and Steel Community Treaty, and as a result, these industries were not subject to the TFEU (Treaty on the Functioning of the European Union). European Coal and Steel Community Treaty set special competition provisions similar to the ones in TFEU. Upon the expiry of the European Coal and Steel Community Treaty, coal and steel industries passed into the normal regime laid down by TFEU. Nonetheless, in Turkey, there has never been such a distinction for the coal and steel industry.

In 1962, the European Commission adopted Regulation $26,{ }^{16}$ which modified the competition rules in agriculture, as there was some tension between the objectives of the common agriculture and competition policies (Monti 2003). In Turkey, the Turkish Competition Board exhibited its attitude with respect to agriculture through the opinion given for many markets within agriculture, such as tea, sugar, and tobacco. Supporting policies, purchases by agricultural governmental institutions,

\footnotetext{
${ }^{14}$ Explanation is taken from Dictionary of Competition Terms published by the Turkish Competition Board.

${ }^{15}$ Turkish Competition Board has accepted this principle and used it in various decisions, such as 15.12.1999 dated and 99-59/639-406 numbered decision, 15.7.2009 dated and 09-33/763-183 numbered decision, 29.4.2009 dated and 09-20/404-99 numbered decision.

${ }^{16} \mathrm{http}: / /$ eur-lex.europa.eu/LexUriServ/LexUriServ.do?uri=CELEX:31962R0026:EN:HTML (no longer in force).
} 
stock costs, and privileges granted to governmental undertakings operating in this industry created anticompetitive effects and necessitated market reforms. The Turkish Competition Board expressed its opinion that the Board should keep its eye on these markets and streamline its approach with the reforms.

EU's Regulation No. 4056/86 was a separate implementing legislation in terms of application of competition rules to maritime transport. However, the block exemption required by this Regulation to liner shipping services has recently been repealed, while tramp vessel services are still benefiting from the exemption. Although Turkey closely follows the rules and precedents of the EU Antitrust Law, Turkey has not adopted a secondary legislation regarding a block exemption for liner conferences. The reason might be that Turkey is located in the Mediterranean Sea and is not neighboring to an ocean that can necessitate special treatment for liner shipping.

On the other hand, the Turkish Competition Board closed two investigations related to the maritime industry, as this industry is exempted in the EU by the Regulation No. 4056/86. In a meeting, it was declared that Turkey is watching the course of reviewing the Regulation No. 4056/86 in the EU and will move upon the latest decisions of the Commission. As the Commission revoked the block exemption for this sector, Turkey is not expected to adopt a relevant legislation lately.

According to the European Antitrust Law, atomic energy, noneconomic aspects linked to the specific nature of sport, trade in arms, ammunitions, and war material are/were subject to special provisions besides the Antitrust Law. Nevertheless, the Turkish Competition Board has not applied or adopted special provisions for these industries to date. They are treated in the same way as any other area of economy and have been applied the Antitrust Act.

Due to many reasons, such as late appointment of the Turkish Competition Board almost three years after the enactment weak public awareness about the welfare advantages of market economy and particularly competition rules, has not been constituted properly. Crucially, the independence of the Turkish Competition Board has not been digested sufficiently by legislative authorities. Thus, much legislation enacted before the Antitrust Act was enacted obstructs or precludes the Antitrust Act's application to the industries that are regulated by the said legislation. Worse than that, even though requesting the Turkish Competition Board's opinion by prime ministry mandate is a must by law for any rule-making activity, almost never has the opinion been requested or even taken into consideration on the several occasions that it has been obtained. As a result, the competition law enforcement appears to be weak with respect to certain industries.

This factual situation leads to a general lack of approach to the special industries. The Turkish Competition Board has many exemplary decisions in this regard. In these decisions, the Turkish Competition Board expresses that it cannot apply the competition rules to the industry in question owing to the special rules prescribed by related laws, and it leaves the dispute to the authority that is competent to apply the related laws to the industry.

One of the prominent examples of this issue is the approach of the Turkish Competition Board toward football-broadcasting rights. In its previous decisions on 
football-broadcasting rights, the Turkish Competition Board had ruled in detail that the scope and duration of exclusive broadcasting rights should be determined in a manner that would impede market foreclosure. However, in the tender realized in January 2010, the Turkish Football Federation has granted exclusive broadcasting rights of the Turkish Super League without dividing the rights concerned into competitive live packages and for 4 years (plus a year of extension right). Although the scope and the duration of exclusive rights could lead to market foreclosure, the Turkish Competition Board opted not to intervene in the tender process. The only reason for the Turkish Competition Board to change its settled enforcement is the new law on the Establishment and Duties of the Turkish Football Federation (TFF). ${ }^{17}$ Article 13 of the law concerned states the exclusive authority of TFF on broadcasting rights as follows:

Article 13 - (1) The TFF Executive Board shall be exclusively entitled to broadcast all the football matches in the territory of the Republic of Turkey on TV, radio, the Internet and via all other similar sound and data carriers, and to organize and plan such broadcasts.

(2) The above-said power particularly encompasses the marketing of the TFF's broadcasting rights centrally and the distribution of the proceeds derived from such rights to Member clubs in such manner as may be decided by the relevant bodies of the TFF.

Because of the authority given to TFF by Article 13 of the Law, the Turkish Competition Board did not monitor the tender process, even though it conflictingly pointed out that "the possibility of obtaining other packages by the broadcaster of Turkish Super League and the 4-year (plus a year of extension right) duration of exclusive rights could lead to prevention of competition."

Moreover, Attorneys Act numbered 1136 and the Law of Independent Accountancy, Independent Accountant Financial Advisorship and Sworn in Financial Advisorship numbered 3568 grant the associations of undertakings the authority to fix the minimum prices and force the undertakings to adhere to a minimum price list, which constitutes a practical infringement of Article 4 of the Antitrust Act. As a concrete example, the decision of the Turkish Competition Board dated 13.11.2003 and numbered 03-73/876(a)-374 ruled that the Attorneys Act is in conflict with the Antitrust Act and shall be adapted and amended in accordance with the competition rules. Unfortunately this advise had been never adopted.

Another contradiction is concerned with municipal laws numbered 5393 and 5216, which provide the municipalities with the power to determine and apply the route, timing, and ticket prices of public transport means. As a matter of fact, public transportation prices are subject to the regulation of municipalities and consequently the supply and demand conditions in the market has no effect on prices. The 26.05.2005 dated, 05-36/458-108 numbered decision and 22.11.2007 dated, 07-87/1103-428 numbered decision of The Turkish Competition Board are relevant examples of the fact that the Turkish Competition Board cannot interfere with the price-fixing actions of municipalities.

${ }^{17}$ The relevant Act numbered 5894 was enacted on 05.5.2009, OG. Date:16.5.2009, Number: 27230. 
Additionally, Article 19 of Banking Law numbered 5411 states the following:

Article $19-(\ldots)$ In mergers, disintegrations and transfers of banks to be carried out pursuant to the provisions of this Law, the provisions of Turkish Commercial Code No. 6762 and, on the condition that the industrial share of the total assets of the banks subject to merger or integration does not exceed twenty percent, the provisions of Articles 7, 10 and 11 of the The Antitrust Act shall not be applied.

Thereby, an exception to the Articles 7, 10, and 11 of the Antitrust Act has been created by another sector-specific law. This controversy has been criticized by EU in its latest progress report about Turkey's accession to the Union.

\subsubsection{Undertakings and the Associations of Undertakings}

Competition rules apply to the behaviors of undertakings and associations of undertakings. Hence, the subject of Turkish Antitrust Law is "undertakings." Prior to the enactment of the Antitrust Act, the term "undertaking" was an unfamiliar concept for the Turkish Legal System. So, the Antitrust Act brought a new legal term into the Turkish Law and defined this term in Article 3. According to this definition "an undertaking is a natural or legal person who produces and sells goods or services in the market, and units which can decide independently and do constitute an economic whole." This definition in fact has two elements: "economic activity" and "independence." Explaining these elements will help us understand the concept.

The meaning of economic activity seems self-evident. When one provides goods or services in exchange for economic benefit, i.e., money, then he/she is engaged in an economic activity. Apparently, corporations, firms, and other commercial entities operating with profit-maximizing incentives are economic entities. However, a profit-making motive is not a condition for economic activity. Natural or legal persons, especially government bodies that lack profit-maximizing motives can be qualified as undertakings provided that they offer goods and services in markets. In that regard, foundations and cooperatives conduct economic activity as well. The Turkish Competition Board endorsed this view in its several decisions including TSE $^{18}$ and ASKI. ${ }^{19}$

The second element, independence, means that the economic unit should determine its own economic and commercial policies without interference or decisive influence of any other natural or legal person. So, independence is an economic, not a legal, concept. For example, if the commercial policies of a company "S" (i.e., subsidiary) are determined by another company "H" (i.e., holding company), then despite having a legal independence, company " $\mathrm{S}$ " is not considered as an undertaking, as it lacks economic independence. For competition law purposes, these two companies are treated as a single "economic unit" and therefore as single

\footnotetext{
${ }^{18}$ Decision of the Turkish Competition Board dated 8.3.2002, numbered 02-13/126-53.

${ }^{19}$ Decision of the Turkish Competition Board dated 8.8.2002 and numbered 02-47/587-240.
} 
undertaking. The question of when and under what conditions an economic unit is controlled by another person or firm could only be determined in specific cases by taking into account all relevant legal and economic factors.

There are two main consequences of this "independence" element. One is that economic relations within the economic unit are beyond the scope of competition law. Accordingly, Article 4 is not applied to commercial agreements between "S" and " $\mathrm{H}$," and the merger between " $\mathrm{S}$ " and " $\mathrm{H}$ " is not covered in Article 7 of the Antitrust Act. There are many illustrations of this application in the Board's decisions, particularly with respect to merger cases. ${ }^{20}$ The second result is concerned with the imputation of the subsidiary's behavior with regard to its parent. As the subsidiary is controlled by the parent company, the subsidiary's legal personality is disregarded, and the parent company is held responsible for the competition law infringement. The practical consequence is that the aggregate turnover figures of the two companies are taken into account when calculating substantive monetary fines. ${ }^{21}$ In its several decisions, the Turkish Competition Board has applied this criterion and, for example, treated a group of companies as a single economic whole as they were controlled by a family. ${ }^{22}$ Also, group exemption regulations explicitly adopt the independence element, and in calculating turnover and/or market share, all "connected" economic units are taken into account. ${ }^{23}$

As seen from these explanations, an undertaking is a very broad concept, and it encompasses every entity engaged in an economic activity regardless of the legal status. It is evident that an undertaking can be a natural person ${ }^{24}$ as well as a legal person. Also, a group of persons, whether legal or natural, may well constitute an undertaking. ${ }^{25}$ The Turkish Competition Board adopts a functional and economic approach just as that adopted by the European Commission.

It should be noted that the ownership structure is not important either. So, stateowned companies are also considered as undertakings and subjected to competition rules unless their acts are purely regulatory in nature. ${ }^{26}$ In fact, given the extensive involvement of government in Turkish economy, decisions concerning state-owned undertakings loom large in the Competition Board's practice. In particular, Article 6 , which governs abuse of dominant position, is frequently applied to state-owned undertakings. ${ }^{27}$

\footnotetext{
${ }^{20}$ Decision of the Turkish Competition Board dated 4.3.2010 and numbered 10-21/264-97.

${ }^{21}$ Although it should be said that economic unit criterion has been occasionally applied inconsistently, especially with regard to the imposition of fines. In some decision, Turkish Competition Board took the turnover figure of the subsidiary, whereas in others, all economic unit. Although there are explicit provisions in the Fine Regulation, recent decisions also indicate inconsistent application.

${ }^{22}$ Decision of the Turkish Competition Board dated 16.1.2001 and numbered 01-04/21-04.

${ }^{23}$ Decision of the Turkish Competition Board dated 25.12.2001 and numbered 01-63/652-174.

${ }^{24}$ Decision of the Turkish Competition Board dated 9.2.2006 and numbered 06-11/130-32.

${ }^{25}$ Decision of the Turkish Competition Board dated 17.7.2000 and numbered 00-26/291-161.

${ }^{26}$ Decision of the Turkish Competition Board dated 13.3.2001 and numbered 01-12/114-29.

${ }^{27}$ Approximately $30 \%$ of all Article 6 decisions involve state-owned undertakings.
} 
The Turkish Antitrust Law also applies to behaviors of associations of undertakings. The Antitrust Act defines the concept in Article 3 and according to that definition, "any kind of associations with or without a legal personality, which are formed by undertakings to accomplish particular goals are considered as associations of undertakings." Here again, the legal form and the purpose of association are irrelevant for competition law purposes. However, it is imperative that the association should not itself conduct economic activity, because in that case, it will be characterized as an undertaking. As a consequence of being subject to competition law, associations and their directors could be held responsible for the competition law infringements (Article 16). Given that associations generally play vital roles in the formation and the sustainability of cartels, imposition of fines on associations might have major deterrent effects on cartels.

\subsection{Overview of Substantive Provisions}

Similar to other jurisdictions that have adopted competition rules, Turkish practice has three pillars of substantive provisions: (a) Restrictive agreements, (b) Abuse of dominant position, and (c) Concentrations.

\subsubsection{Restrictive Agreements}

\subsubsection{Collusive Behavior}

According to Article 4 of the Antitrust Act, agreements and concerted practices between undertakings, and decisions and practices of associations of undertakings that have as their object or effect or likely effect the prevention, distortion, or restriction of competition directly or indirectly in a particular market for goods or services are illegal and prohibited.

The article mentions half a dozen possible examples of restriction of competition. However, these examples are not numerus clausus, and so the Turkish Competition Board is not limited by these listed examples of restriction. Because the Turkish Competition regime is set up to protect the competitive environment in the market, every action of the undertakings that falls into the scope of restrictive agreements, concerted practices, and decisions and practices of associations of undertakings will be considered illegal, regardless of whether the particular action is listed under Article 4 or not. The examples that are listed under the mentioned article are as follows:

(a) Fixing the purchase or sale price of goods or services, elements such as cost and profit which form the price, and any terms of purchase or sale.

(b) Partitioning markets for goods or services, and sharing or controlling all kinds of market resources or elements. 
(c) Controlling the amount of supply or demand in relation to goods or services, or determining them outside the market.

(d) Complicating and restricting the activities of competing undertakings, or excluding firms operating in the market by boycotts or other behavior, or preventing potential new entrants to the market.

(e) Except for exclusive dealing, applying different terms to persons with equal status for equal rights, obligations, and acts.

(f) Contrary to the nature of the agreement or commercial usages, obliging to purchase other goods or services together with a good or service, or tying a good or service demanded by purchasers acting as intermediary undertakings to the condition of displaying another good or service by the purchaser, or putting forward terms as to the resupply of a good or service supplied.

The Agreement

An "Agreement" in the Turkish Antitrust Law practice has a broader meaning, and the Turkish Competition Board attributes a wider scope to it, if it is compared to contracts law, in its decisions. The most important perquisite for an agreement in competition law is the intention of the parties to take actions as mutually agreed. As a matter of fact, there are no adjective requirements for the Turkish Competition Board to decide whether there is an agreement or not. If the parties somehow feel themselves as if they are bounded with the terms of agreement, it is enough to state that there is an agreement.

The agreements restricting competition are also broadly discussed in the Turkish Competition Board. In its recent decision on Poultry Cartel, ${ }^{28}$ the Turkish Competition Board clarified the notion of agreement with following words "rationale of the Article 4 of no. 4054 expressly states that, agreement should not carry all the requirement arise from contract law. The concept of agreement in competition law is used to define any mutual consent among the parties."

\section{Concerted Practices}

It is quite easy to assert that the common approach in the Turkish Antitrust Law on concerted practices is very similar to the European Antitrust Law enforcement. However, there is one very unique difference in Turkish legislation, which is "the presumption of concerted practice". Article 4/III and 4/IV of the Antitrust Act define this presumption and grant the Turkish Competition Board a very strong weapon. The mentioned provision is as follows:

Cases where the existence of an agreement cannot be proved, or that the price changes in the market, or the balance of demand and supply, or the operational areas of undertakings

\footnotetext{
${ }^{28}$ Decision of Turkish Competition Board dated 25.11.2009 and numbered 09-57/1393-362, para. 2460.
} 
are similar to those markets where competition is prevented, distorted, or restricted constitute a presumption that the undertakings are engaged in concerted practice.

Each of the parties may relieve itself of the responsibility by proving not to engage in concerted practice, provided that it is based on economic and rational facts.

At a glance, the presumption of concerted practice seems to be different from the EU practice. However, if we look at the Woodpulp ${ }^{29}$ and Dyestuffs ${ }^{30}$ cases, we can see that the practices of both jurisdictions are parallel. The main difference is that in Turkey, the presumption is explicitly codified under the Antitrust Act. Consequently, the presumption of concerted practice shows its affects mostly for the burden of proof. The application of the presumption shifts the burden on the alleged party, and it is often hard to prove innocence. Thus, to prevent the unfair consequences that might arise from exploitation of the presumption of concerted practice, the Turkish Competition Board set forth its approach explicitly in various decisions. For instance the concerted practice are clearly defined in the Turkish Competition Board's Newspaper ${ }^{31}$ decision:

1. There must have been positive contacts between the parties such as meetings, discussions, exchanges of information, which are generally expressed orally or in writing,

2. Such contacts must have been aimed at influencing the market behavior and especially eliminating the uncertainty of an undertaking's future competitive behavior in advance,

3. They must have influenced or changed the commercial behavior of the undertaking concerned in a manner that cannot fully be explained with reference to competitive effects.

\section{Decisions of Associations of Undertakings}

Article 4 of the Antitrust Act also prohibits the behaviors of undertakings that restrict competition, through associations of undertakings. Associations of undertakings are defined in Article 3 of the Antitrust Act: "any kind of associations with or without a legal personality, which are formed by undertakings to accomplish particular goals."

As Sanl1 stated, "associations of undertakings are also a subject of the Antitrust Act under the scope of Article 4. Thus, (...) it is possible to open an investigation against a conduct of a decision of associations of undertakings" (Sanl1 2000a, p. 83). Moreover, it makes no difference whether the association in question has a legal entity or not. The Turkish Competition Board stated this point so clearly in its

\footnotetext{
29 "Woodpulp II" Cases C-89, 114, 116 to 117, 125 to 129/85, A. Ahlstroem Osakeyhtiö and others v. Commission, (1984) ECR 1679.

30 "Dyestuffs", Case 48/69, ICI v. Commission (1972) ECR 619.

${ }^{31}$ Decision of Turkish Competition Board dated 17.07.2000 and numbered 00-26/291-161.
} 
Press Monitoring ${ }^{32}$ decision that the Board applied an injunction decision to BIAK, which is a joint industrial committee for monitoring the circulation of printed press in Turkey,

BIAK is a committee, which does not have a legal entity, and that is formed by representatives of advertising agencies, advertisers, channel organizations that came together in order to carry out and finance investigations (...) run and coordinate the projects.

\subsubsection{Test of Illegality: Restriction of Competition}

\section{Horizontal and Vertical Restraints}

The business relations between the undertakings may be either horizontal or vertical. Restrictions of competition, horizontally or vertically, by undertakings fall under the scope of Article 4 of the Antitrust Act. Similar to practices of other jurisdictions, the approach of the Turkish Antitrust Law regime is different from horizontal and vertical restraints. The main rationale behind this approach is the basic fact that generally the horizontal restraints create benefit for the society in limited circumstances, whereas vertical restraints may give rise to economic efficiency under certain conditions. Thus, the Turkish Competition Board uses a much more per se approach to the horizontal restraints of competition.

On the other hand, vertical restrictions of competition may create positive effects and heighten the social welfare. This characteristic of the vertical agreements makes the assessment under Article 4 much more broad and complex. To clarify this approach to the vertical agreements, the Turkish Competition Board has published numerous communiqués and guidelines on vertical relations.

The common vertical agreements that restrict competition in practice are exclusive distribution agreements, non-compete obligations, and market sharing agreements between the undertakings that operate in different levels of the supply chain. The Turkish Competition Board makes a case-by-case analysis to reveal whether the efficiency gained by the agreement is greater than the loss due to the restriction of competition. However, if a vertical agreement fulfills the conditions on block exemption, the agreement is automatically exempted from the application of Article 4 of the Antitrust Act, and it is not necessary for that agreement to make a notification to the Turkish Competition Authority. Horizontal agreements on the contrary are usually subject to individual exemption scrutiny.

\section{Per Se Prohibitions and Rule of Reason}

Most of the horizontal restrictions listed in Article 4 are subject to per se analysis and directly considered void and illegal. Also, vertical restraints such as resale price

\footnotetext{
${ }^{32}$ Decision of Turkish Competition Board dated 04.03.1999 and numbered 99-13/99-40.
} 
maintenance (RPM) and other hard-core restrictions are prohibited by law per se. Contrary to Article 101 of TFEU, Article 4 of the Antitrust Act does not contain any de minimis provisions. Hence, the Turkish Competition Board is authorized to investigate any kind of agreements between undertakings and to impose fines, even though the stated agreement does affect a minor portion of the economy. Such a per se approach is used in many of the investigations of the Turkish Competition Board, such as its Marmara Region Cement ${ }^{33}$ decision.

\begin{abstract}
If an anticompetitive aim is clearly observed in an agreement, the agreement itself or the provisions that distort competition would form a "per se" competition infringement. In such case, there is no need to examine the effect of the agreement on competition. Restrictive agreements would form a structural case that parties would discard their own independent competitive activities on behalf of their common interests. Because of such reason, only being a part of a restrictive agreement is prohibited as well, even if the agreement had not showed effect.
\end{abstract}

Other important point to notice is Article 4/I, which also prohibits agreements that "likely effect the prevention, distortion or restriction of competition directly or indirectly." If an agreement does not affect competition but there is a chance that it might affect competition in the future, then the stated agreement is also prohibited. So, the Turkish Competition Board has a broad discretion to decide whether an agreement is anticompetitive or not.

If Article 4 is assessed from a per se point of view, it can be said that the examples listed in the second paragraph of the article set a situation that make per se analysis nearly impossible, as it has listed nearly all possible (at least the most common ones) per se restrictions. In other words, if an agreement falls under the scope of one of the listed examples, the agreement in question will be deemed to restrict competition, prima facie. However, if Article 4 is assessed together with Article 5 (exemption provision), we can say that there is a form of rule-of-reason analysis for every case. Also, the exemption analysis is made for every investigation (Sanlı 2000a, p. 99).

Also, if the investigation that the Turkish Competition Board relies on the grounds of concerted practice, then the Turkish Competition Board is bound to make a rule-of-reason analysis. This situation occurs from the above-mentioned presumption of concerted practice. Consequently, making a per se analysis and using the presumption of concerted practice would not give any chance to the undertaking to defend itself. As a result, the Turkish Competition Board uses a rule-of-reason analysis in cases where the allegation is based on concerted practices.

Another important point to mention is that even in the cases where a horizontal relation is founded to realize some higher causes, such as protecting environment, and even if a governmental institution has an encouraging effect on a cartel, a fine

\footnotetext{
${ }^{33}$ Decision of Turkish Competition Board dated 5.12.2005 and numbered 05-81/1118-320.
} 
may be imposed by the Turkish Competition Board. Accumulator ${ }^{34}$ Decision is a good example for this situation:

None of the actions that are admitted as infringement would be grounded by the APAK Regulation ${ }^{35}$ or incentives of the Ministry of Environment and Forest. Incentives of the Ministry is for providing the management compatible with environment, of waste accumulators and for forming a system about this matter and supporting formation of associations. Enterprises claiming that they have to comply the APAK Regulation are also obliged to comply with the Antitrust Act on the Protection of Competition.

\section{Leniency}

On February 2009, the Turkish Competition Board introduced two regulations on leniency and monetary fines. The aim of the new leniency regime is to help the Turkish Competition Board to detect cartels and also deter them from the very beginning. Leniency is simply, giving immunity from sanctions, mainly fines, to the undertaking which has revealed evidence concerning the cartel of which it was a member. Another implication of these Regulations is that the undertaking's managers and employees having active participation to the violation can also be fined up to $5 \%$ of the fine that is imposed on the employer undertaking.

In order to apply the Leniency regulation effectively, the scope and the magnitude of fines should be foreseeable, and the undertakings should be able to assess the consequences of their actions. ${ }^{36}$ So, the Regulation on Monetary Fines (the Fine Regulation) also came into effect on the same day as the Leniency Regulation.

For leniency applications, first undertaking that submits the information and evidence independently from its competitors, shall be granted immunity from fines on condition that the Authority does not have, at the time of the submission, sufficient evidence to find the violation of Article 4 of the Antitrust Act. So, the first undertaking that applied for the leniency will be granted a full immunity, but undertakings that could not take the first place can also apply for the leniency to get a reduction from their fines. The reduction scheme is given below:

(a) The fine to be imposed on the first undertaking shall be reduced by one third to half.

(b) The fine to be imposed on the second undertaking shall be reduced by one fourth to one third.

(c) The fines to be imposed on other undertakings shall be reduced by one sixth to one fourth.

\footnotetext{
${ }^{34}$ Decision of Turkish Competition Board dated 20.5.2008 and numbered 08-34/456-161, p. 79 .

${ }^{35}$ An industry-specific regulation found by the Turkish Competition Board to facilitate an environment that makes it easy to form a cartel.

${ }^{36}$ The system before the adoption of the Fine Regulation granted the Turkish Competition Board a broad discretionary power to impose a fine ranging from 0 to $10 \%$ of the annual turnover.
} 


\subsubsection{Exemption}

Article 5 of the Antitrust Act and the Communiqué Regarding Vertical Agreements No. 2002/2 (Communiqué No. 2002/2) published by the Turkish Competition Board regulates the exemption procedure in general. Article 5 of the Antitrust Act is very similar to Article 101/3 of the TFEU, and it assesses the impact of an agreement on the general public. If the net effect of the agreement in question is positive despite restricting competition, the agreement in question will be individually exempted from the application of Article 4 of the Antitrust Act. The test used to assess whether an agreement fulfills the requisitions to acquire an exemption is stated in Article 5.

(a) Ensuring new developments and improvements, or economic or technical development in the production or distribution of goods and in the provision of services

(b) Benefitting the consumer from the above-mentioned

(c) Not eliminating competition in a significant part of the relevant market

(d) Not limiting competition to more than what is compulsory for achieving the goals set out in subparagraphs (a) and (b)

In addition to the provisions of the Antitrust Act, the Communiqué No. 2002/2 exempts the vertical agreements that fulfill the conditions set in the Communiqué. The block exemption will be applied if the market share of the supplier in the relevant market to which it supplied the goods and services in a vertical agreement does not exceed 40\% ${ }^{37}$ The block exemption is also applied if the market share of the buyer does not exceed $40 \%$ in an exclusive supply agreement. However, the agreement must not include the hard-core restrictions, which are stated in Article 4 of the Communiqué no. 2002/2.

Also, the Vertical Guidelines published by the Turkish Competition Board make a detailed assessment of the vertical agreements, and it is very instructive for the undertakings. Finally, it is notable that the assessment of both individual and block exemption is made by the parties of an agreement, and it is not necessary to make a notification to the Turkish Competition Board. Provided that an agreement does not fulfill the conditions of exemption or in order to avoid legal ambiguity, the parties are free to make a negative clearance and/or exemption notification to the Turkish Competition Board.

\subsubsection{Abuse of Dominant Position}

Article 6 of the Antitrust Act prohibits abusive behavior of dominant undertakings. According to the first paragraph, "the abuse, by one or more undertakings, of their

\footnotetext{
${ }^{37}$ This threshold is determined as $30 \%$ in EU Regulation.
} 
dominant position in a market for goods or services within the whole or a part of the country on their own or through agreements with others or through concerted practices is illegal and prohibited." As it can be observed, the wording of the paragraph seems quite complex as it refers to agreements and concerted practices between undertakings. However, the logic of Article 6 is very simple: it controls the unilateral behavior of dominant undertakings. Holding a dominant position in the market is not unlawful, but it is the behavior that is proscribed provided that it impairs the competition in the market. The nature of abusive behavior whether implemented through agreements or concerted practices is irrelevant.

The second paragraph lists some examples of abusive behavior, and this list is not an exhaustive catalogue of what kinds of behavior are regarded as abusive. According to the second paragraph, some examples of abusive behaviors are as follows:

(a) Preventing, directly or indirectly, another undertaking from entering into the area of commercial activity, or actions aimed at complicating activities of competitors in the market.

(b) Making direct or indirect discrimination by offering different terms to purchasers with equal status for the same and equal rights, obligations, and acts.

(c) Purchasing another good or service together with a good or service, or tying a good or service demanded by purchasers acting as intermediary undertakings to the condition of displaying another good or service by the purchaser, or imposing limitations with regard to the terms of purchase and sale in case of resale, such as not selling a purchased good below a particular price.

(d) Actions that aim at distorting competitive conditions in another market for goods or services by means of exploiting financial, technological, and commercial advantages created by dominance in a particular market.

(e) Restricting production, marketing, or technical development to the prejudice of consumers.

In order to apply Article 6, at least two conditions must hold: "dominance in the relevant market" and "abusive behavior." There is no exemption provision in Article 6; therefore, dominant undertakings' efficiency defenses (objective justification) may be recognized under the concept of abuse. These two conditions are analyzed in detail below.

\subsubsection{Dominant Position}

Article 6 deals with the behavior of monopolies and dominant undertakings. To be caught by the Article 6, one should first establish dominance in the relevant market. Market dominance is an economic concept, and it merely refers to a high degree of economic power. Article 3 of the Antitrust Act defines the following concept: "The power of one or more undertakings in a particular market to determine economic parameters such as price, supply, the amount of production and distribution, by acting independently of their competitors and customers." The legal definition seems to 
be in accordance with the economic theory, which basically demotes the description to "power over price."

However, neither legal nor economic definition solves the problem of determining dominance in a particular case. Probably, the main question that the competition law seeks to answer is the degree of economic power that is is necessary for dominance in the market or the conditions under which an undertaking has a power over price.

One way to deal with this problem is looking directly at the performance, i.e., profit levels of the undertakings at hand. However, there are a variety of causes that may complicate this analysis, and therefore, just as other competition authorities tend to prefer, the Competition Board measures the dominance by looking at two factors: "market shares" and "entry barriers."

The preliminary filter to determine the dominance is the "market share" of the undertaking. To determine the market share, first the relevant market is defined, which is not unique to dominance analysis. After determining the relevant market, the shares of undertakings and their rivals are calculated. Although market share values in the Turkish Competition Board's decisions are generally omitted due to trade secrecy concerns, it is still possible to infer some implications from the decisions. According to the Turkish Competition Board's case law, shares above $40 \%$ create risk of dominance, and shares beyond $60 \%$ can give rise to a presumption of dominance. It is interesting to note that, although in theory, low market shares may trigger the risk of dominance, when one looks at the actual practice of the Turkish Competition Board, the dominant undertaking has held market shares in excess of 70 or even $80 \%$ in the majority of cases. So, it would not be an overstatement to say that the Turkish Competition Board generally requires higher market shares when establishing dominance. Mere existence of high market shares is not deemed sufficient. High market shares should last for some time and market shares of the rivals of the undertaking should be significantly smaller.

The second factor in determining dominance is entry conditions in the market. It is well established that dominance does not exist without high entry barriers because if entry is easy, other firms will be able to exert competitive pressure on the undertaking by holding high market shares. There is no common understanding on the definition of "entry barrier" in economic theory; however, in competition law practice, the issue seems to be settled. The concept is broadly defined, and any impediment/barrier challenging the entrant is regarded as an entry barrier. Apparently, with this definition one could not think of any market without entry barriers. So, the concept is a relative one.

What are entry barriers? Case law provides an extensive list of factors that are recognized as entry barriers. Of course, primary examples are legal ones. Licenses, other intellectual property rights, and entry and exit regulations are considered as significant, if not absolute, entry barriers. ${ }^{38}$ Market conditions could also help the undertaking to protect its position in the market and deter entry. In this regard,

\footnotetext{
${ }^{38}$ Decision of the Turkish Competition Board dated 6.11.2000 and numbered 00-44/472-257.
} 
economies of scale and scope, network externalities, and high proportion of sunk costs also indicate high entry barriers. The behavior and performance of the undertaking could also make entry more difficult for newcomers. For example, a wellorganized distribution system, idle capacity, advertising and brand recognition, limit pricing, product differentiation, high quality of the product, innovation, and deep pockets are also deemed to contribute to the dominant position. ${ }^{39}$ As seen from the examples, there are many factors that may indicate dominance, and the Turkish Competition Board shows no reluctance to characterize any other factor as barrier to entry.

Article 6 applies not only to single dominance, which is usually the case, but also to joint/collective dominance situations. The wording of the article explicitly refers to an abuse "by one or more undertakings," and the definition of dominance in article 3 mentions "one or more undertaking's dominance." Joint dominance used to be a controversial topic in the European Antitrust Law; however, the recent case law seems to have put an end to that controversy. ${ }^{40}$ Joint dominance refers to situations where due to the economic links among them, two or more undertakings can act independently from their competitors and customers. It is necessary that joint dominant undertakings should act as a single entity. The economic link could be established by agreements or by market conditions. Especially in tight oligopoly markets where characteristics of the market are prone to tacit collusion, it is assumed that such links may exist without an agreement.

The Turkish Competition Board has embraced the principles of European case law and surprisingly has been very enthusiastic to apply collective dominance. Out of 23 Article 6 infringements decided by the Turkish Competition Board, four cases involve joint dominance. In its early years of enforcement, two leading media companies and the joint venture that was established to undertake their distribution operations in the daily newspaper market were found to be collectively dominant and they abused their position by refusing to deal with a competitor. ${ }^{41}$ Just a year after, the Turkish Competition Board reached a very similar verdict involving the same undertakings and imposed penalties. ${ }^{42}$ In both of the decisions, the economic links were said to be established by agreements, the joint venture company. In fact, it was doubtful whether resorting to the concept of joint dominance was necessary as these two undertakings were also found to have violated Article 4 of the Antitrust Act. In 2003, the Turkish Competition Board has imposed harsh penalties to two leading mobile phone operators due to collective refusal to deal practices implemented through 22 consecutive months. ${ }^{43}$ Here, there was no evidence of an agreement or a concerted practice. With this decision,

\footnotetext{
${ }^{39}$ Decision of the Turkish Competition Board dated 29.12.2005 and numbered 05-88/1221-353.

${ }^{40}$ Compaigne Maritime Belge NV v. Commission (1996) ECR II 1201 (1997) 4 CMLR. 273.

${ }^{41}$ Decision of the Turkish Competition Board dated 17.7.2000 and numbered 00-26/292-162.

${ }^{42}$ Decision of the Turkish Competition Board dated 14.12.2000 and numbered 00-49/529-291.

${ }^{43}$ Decision of the Turkish Competition Board dated 9.6.2003 and numbered 03 -40/432-186.
} 
the Turkish Competition Board has endorsed the view that economic links can be established solely by market conditions and that joint dominance can be used as a weapon to combat the oligopoly problem. ${ }^{44}$

\subsubsection{The Concept of Abuse}

It is not illegal to hold a dominant position in the relevant market, but what is prohibited by the Antitrust Act is the abuse of this position. The Antitrust Act imposes special responsibility on dominant undertakings not to allow their conduct to impair the competition on the market. The problem with this proposition is that the scope of the responsibility is not entirely clear. Abuse is an elusive concept, and despite the nonexhaustive list of abusive behavior enumerated under Article 6/2, it requires interpretation. In that regard, the European case law and the doctrine are primary resources in understanding the concept and the Turkish Competition Board frequently refers to the European case law.

Abuse is an objective concept. ${ }^{45}$ It is irrelevant whether the dominant undertaking has an intention of infringing Article 6. Conduct could be abusive, even if, for instance, it harms the competitive structure in the downstream markets where the dominant undertaking has no operations and does not have a potential to do so. ${ }^{46}$ Accordingly, it is not necessary that the dominant undertaking should have benefited from the consequence of its abusive behavior. What matters is the harmful effect of the conduct on the market. This understanding of abuse is endorsed by the Turkish Competition Board in several cases. However, it should also be noted that in certain types of abuses, such as predatory or selective pricing, intention is generally the essential part of the infringement.

Abuse can take a variety of forms. An agreement, contract, or purely unilateral decision, or even inaction can be characterized as abusive behavior. Therefore, it is not possible to exhaustively enumerate the types of abusive behavior. Taking into account its effects on the competitive process, abuse is generally analyzed under two main categories: "exploitative" and "exclusionary" abuses. This classical categorization is helpful in understanding the concept; therefore, the main types of abusive behavior are analyzed under two categories below. It should be mentioned

\footnotetext{
${ }^{44}$ In this decision, the Turkish Competition Board listed some nonexhaustive conditions, which may amount to finding of economic links. These conditions are: few market players, mature market structure, stagnant and moderate increase in demand, low demand elasticity, homogenous products, similar cost structures, similar market shares, transparent market conditions, low rate of innovation, idle capacity, high entry barriers, no market power on the buyer side, no potential competition, some sort of connection between relevant undertakings, possibility of retaliation, and lack of price competition.

${ }^{45}$ Decision of the Turkish Competition Board dated 23.8.2002 and numbered 02-49/634-257, p. 54 .

${ }^{46}$ Decision of the Turkish Competition Board dated 20.4.2009 and numbered 09-16/374-88.
} 
that there is no rigid demarcation between these categories; the same behavior may fit in with both categories depending on the circumstances of the case.

\section{Exploitative Abuses}

The term abuse in fact evokes exploitation, and that is normally what one expects from dominant undertakings. A dominant undertaking exploits its customers by charging high prices and/or by supplying poor-quality products and/or by dictating unfair terms and impairing innovation. These behaviors result in inefficiency and directly harm consumers. Given that this is the public harm that the competition law intends to prevent, it is natural that Article 6 explicitly prohibits exploitative abuse. By prohibiting these behaviors, inefficient practices will be deterred, and social/ consumer welfare will be ensured. Article 6 explicitly confirms this logic; all these practices are proscribed by the examples of abuse set out in the second paragraph. Article 6/2 (b) prohibits discriminatory practices, 6/2 (c) bans tying, and 6/2 (e) forbids impairing innovation and restricting the output.

Nevertheless, the actual practice of the Turkish Competition Board has not been entirely compatible with this theoretical logic. Compared to exclusionary abuses, the Turkish Competition Board has not been keen to apply Article 6 to exploitative abuses. 34\% of all (205) Article 6 decisions involve exploitative abuses, and only in four cases of 23 , abuse was established ${ }^{47}$ So, the majority of exploitative abuse allegations were denied by the Turkish Competition Board, and the verdict of those four cases generated a lot of controversy.

Not surprisingly, this practice is in line with the European Commission's attitude. One would then wonder why the theoretical logic contradicts the practice. The explanation lies in the economic thinking. If an undertaking charges high prices and/or offers poor-quality goods, this will provoke entry into the market and increase competition. So, the market will itself correct this failure without costly and imperfect government interference. Besides, there are practical problems associated with enforcing competition law to exploitative practices. To be more specific, it is difficult to identify the parameters of intervention, and even if this could be done, there is a problem of remedy. Therefore, perhaps the (second best) solution is not to interfere at all (Sanl1 2000b, p. 87 et. seq.).

This line of thinking has affected the Turkish Competition Board, and despite the existence of a few infringement decisions, enforcement policy toward exploitative abuses seems reluctant. For example, there are almost no cases about dictating unfair conditions and impairing innovation. Unfair pricing and price discrimination have been the main types of exploitative practices that the Turkish Competition Board has dealt with, and there are only four decisions where the behavior was

\footnotetext{
${ }^{47}$ Considering that there are in twenty-three cases the Turkish Competition Board determined that the Article 6 was violated, overwhelming majority (\%83) of infringement decisions involve exclusionary abuse.
} 
found abusive within the meaning of Article 6. Among the four infringement decisions, three cases concern price discrimination and one case relates to unfair pricing. However, that ratio is reversed when it comes to the percentage values involving all cases decided by the Turkish Competition Board: $24 \%$ of all cases relate to unfair pricing. This is surprisingly high given the general tendency toward these practices. One probable reason is that state-owned monopolies still have significant influence on the Turkish economy, and a large fraction (30\%) of Article 6 cases relate to practices of state-owned monopolies.

The cases involving price discrimination exhibit interesting features as different legal standards have been applied. In the first case, the CINE 5, besides two conventional conditions, the Turkish Competition Board required that the discrimination should put at least one customer in a competitive disadvantage vis-a-vis its competitors. ${ }^{48}$ So, there should be a negative effect in the competitive conditions of downstream markets to label the conduct as abusive. However, in the two subsequent cases, the IBOIAŞ ${ }^{49}$ and IZOTAŞ, ${ }^{50}$ both of which involved bus-station operators holding monopoly positions in their markets, the Turkish Competition Board, after deliberating the issue, did not insist on this condition and applied Article 6, even though there was no competitive harm caused. One should note that these two cases closely resemble the practice of the European Commission in a case where bus and airport monopolies' discriminatory prices were found to be abusive despite the fact that the competitive disadvantage condition was missing. ${ }^{51}$ Another point that further complicates the issue of discrimination is that in appeal, the Council of State, appeal court for the decision of Turkish Competition Board quashed the first decision on the ground that pricing policies adopted by dominant undertakings were lawful as it was objectively determined, was not beyond the regulatory cap, and enabled the small and medium-sized TV stations to enter the market. So the pricing policy was, in fact, perceived as a discount. After this decision of reversal, it is unclear whether exploitative discrimination will fall within Article 6.

The sole unfair pricing case involves a state-owned undertaking, the BELKO, operating in coal distribution and sales in Ankara. ${ }^{52}$ The coal was used for residential heating; accordingly, it was consumed by a large fraction of the inhabitants, and the demand was inelastic as at that time substitutes were limited. The undertaking had a legal monopoly, and therefore, there was no prospect of entry. The Turkish Competition Board determined that the BELKO was charging very high prices for coal when compared to the prices of coal sold in other cities, and was abusing its dominance by unfair pricing. Benchmarking method indicated that the price of coal was almost $60-70 \%$ higher than the prices in neighboring markets. The unusual

\footnotetext{
${ }^{48}$ Decision of the Turkish Competition Board dated 11.10.1999 and numbered 99-46/500-316.

${ }^{49}$ Decision of the Turkish Competition Board dated 23.9.2005 and numbered 05-60/893-242.

${ }^{50}$ Decision of the Turkish Competition Board dated 11.1.2007 and numbered 07-01/1-1.

${ }^{51}$ OJ (1999) L 69/31, (1999) 5 CMLR 103, upheld on appeal Case 163/99, Portugal v. Commission, 29.3.2001; also see Zaventem decision OJ, dated 12.9.1995, L 216.

${ }^{52}$ Decision of the Turkish Competition Board dated 8.7.2009 and numbered 09-32/703-163.
} 
thing about the case was that the BELKO was making losses due to operational inefficiency and it was obvious that Belko was subsidizing other municipality firms and activities. So, the BELKO argued that the pricing could not be considered abusive, given that it was not making profit. The Turkish Competition Board analyzed this argument and determined that it was true. Nevertheless, the Turkish Competition Board rejected the defence on the grounds that profit is not required for unfair (excessive) pricing. In effect, BELKO was punished because of its inefficiency. With this formulation, it is accepted that Article 6 can be used to control the performance of the dominant undertakings.

\section{Exclusionary Abuses}

There is no doubt that Article 6 covers exclusionary abuse as the second paragraph explicitly lists exclusionary practices as examples of abusive behavior. In fact, Article 6 has been more frequently applied to the anticompetitive practices of dominant undertakings. To be more precise, $65 \%$ of all Article 6 decisions involve anticompetitive abuses and, as mentioned above, the proportion of anticompetitive abuses in infringement decisions is much higher. These figures are in conformity with the general tendency in the EU and in the US case law. Given the problems associated with applying competition law to exploitative abusive behavior, competition authorities are seemed to be less reluctant to combat with anticompetitive abuses.

Anticompetitive abuse simply refers to exclusionary practices aimed at actual and potential rivals. Here, the motivation of the dominant undertaking is clear: to exclude the actual and the potential rival from the market, and thereby maintaining and increasing its market share. The main concern of the competition law is protecting the rivals to preserve the competitive structure of the market. So, the anticompetitive behavior does not actually directly harm the competitive parameters (or the performance) of the market. However, if the competition authorities do not interfere in time, there is a probability that the market concentration may increase, which in turn could negatively affect the performance of the market.

Application of Article 6 to anticompetitive abuses is not without problems. As seen from the definition, the behavior appears competitive on the face of it, and it does not produce harmful results per se. There is a likelihood that the dominant undertaking is actually competing on the merits despite the fact that its rivals are injured and are even excluded from the market as a result of its practices. For instance, the dominant undertaking, due to economies of scale or productivity, may well drive its competitors out of business by lowering its prices. Are we going to characterize this as anticompetitive abuse? So, the main question here is the merits on which dominant undertakings are allowed to compete. The jurisprudence and case law on anticompetitive abuse seek to answer this question by demarcating exclusionary practices from efficient but aggressive commercial policies.

When we look at the case law of the Turkish Competition Board, we observe that a variety of practices fall within the category of exclusionary abuses. The pricing practices probably constitute the main subcategory as they comprise a 
range of pricing schemes such as "predatory pricing," "selective pricing," "price squeeze," and "discriminatory pricing." Almost half of the infringement decisions and more than two third of all cases involve a pricing behavior. Among them, price discrimination and predatory pricing cases are very common. An interesting observation is the proportion of "refusal to deal" cases. The Turkish Competition Board dealt with too many "refusal to deal" cases, and in five out of 23 infringement decisions, the refusal was found to be abusive.

To have a better understanding of the current practice on exclusionary abuse, it would be useful to take a look at some of the leading case laws of the Turkish Competition Board. As just mentioned, there are several pricing policies that are proscribed as abusive. Among them predatory and discriminatory pricing cases loom large. Exclusionary type of discriminatory pricing can take very different forms, and for this reason, it is problematic to recapitulate the Turkish Competition Board's practice on this matter. Besides, the case law concerning discrimination seems unsettled as there have been contradictory judgments. ${ }^{53}$ In contrast, the practice about predatory pricing appears to be more predictable. Although the Turkish Competition Board found abusive behavior only in two predatory pricing cases, there have been many cases illuminating the attitude of the Turkish Competition Board.$^{54}$ For instance, upon a complaint made against the Coca Cola Company, the Turkish Competition Board denied the allegations after carefully analyzing the facts of the case, though it gave a comprehensive verdict articulating the legal test of predatory pricing. ${ }^{55}$ According to the decision, to establish a successful case on predatory pricing, three conditions must be satisfied: Dominance, extraordinarily low prices, and exclusionary intent. The Turkish Competition Board has also explained the meaning of extraordinarily low prices. Referring to European case law, prices below average variable costs were in principle regarded as predatory; however, in some cases, prices above average variable costs but below average total costs might be deemed as predatory. This could especially be the case when the economic investment requires high fixed costs, and in this case, there is a special emphasis on the intent requirement. Another condition that is indirectly stipulated is that the low pricing should last for a certain period. Short-term low pricing indicates that the dominant undertaking acted with a motive other than exclusion. Hence, according to the Turkish Antitrust Law, recoupment is not deemed necessary for establishing a case on predatory pricing.

Both infringement decisions on predatory pricing were committed by the Turk Telecom; Turkish fixed-line telephony incumbent and pricing scheme have the characteristics of (vertical-predatory) price squeeze. In recent years, there have

\footnotetext{
${ }^{53}$ For an interesting judgment on discrimination see Decision of the Turkish Competition Board dated 20.4.2009 and numbered 09-16/374-88.

${ }^{54}$ Decision of the Turkish Competition Board dated 2.10.2002 and numbered 02-60/755-305; Decision of the Turkish Competition Board dated 19.11.2008 and numbered 08-65/1055-411.

${ }^{55}$ Decision of the Turkish Competition Board dated 23.1.2004 and numbered 04-07/75-18.
} 
been numerous complaints ${ }^{56}$ about the price squeezing behavior, especially in the telecommunications industry. So, the latest decision, which was rendered in 2008 , is important in the sense that the Turkish Competition Board set the legal standard and clarified the controversy surrounding the predatory price squeeze. According to this decision, to establish a successful case on price squeeze, six conditions must hold: the undertaking must be vertically integrated; it should have a super dominant position in the upstream wholesale market; the input produced in the upstream wholesale market should be an essential facility for the undertakings operating at the retail level including both the dominant undertaking and its rivals; the price demanded for the essential facility should be so high that it is not possible for an equally efficient competitor in the downstream retail market to operate profitably given the level of retail prices; as a result of the pricing behavior, competition should be negatively affected in the downstream retail market; and finally, there should be no objective justification for the pricing behavior. These conditions indicate that the Turkish Competition Board followed the precedents of the European case law $^{57}$ and secondary legal documents ${ }^{58}$ were explicitly referred in the decision.

Another pricing practice that was found abusive was selective pricing. The decision ${ }^{59}$ involved the pricing behavior of a glass manufacturer, Anadolu Cam, in a bidding process that was alleged to have exclusionary effect on the sole rival, Marmara Cam. Anadolu Cam had a dominant position with $90 \%$ market share, and throughout the bidding process of the major glass purchaser, it implemented a selective pricing scheme. According to the facts of the case, Anadolu Cam lowered its prices in bids where it had the rival, Marmara Cam, and increased its prices where it faced no competition. Even though its lowest prices were not below its costs, the Turkish Competition Board found the pricing scheme illegal under Article 6. According to the Turkish Competition Board, four conditions of selective pricing were met in the present case. These conditions are as follows: the undertaking in question should be evidently dominant; there should be only one rival in the market; clear evidences should indicate that the dominant undertaking has acted with exclusionary motive. As it is well known, selective pricing is a matter of controversy in European Antitrust Law; however, this did not prevent the Turkish Competition Board from labeling this kind of profitable pricing as abusive. However, there have been no other cases of selective pricing, and it is unclear whether this precedent will be followed in the future.

As mentioned, there have been several refusal-to-deal cases, and in five of them, dominant undertakings were held responsible and subjected to monetary fines. In

\footnotetext{
${ }^{56}$ Decision of the Turkish Competition Board dated 4.7.2007 and numbered 07-56/634-216.

${ }^{57}$ Case COMP/38.784 - Wanadoo España vs. Telefónica, 4.7.2007.

${ }^{58}$ Notice on the Application of the Competition Rules to Access Agreements in the Telecommunications Sector, Framework, Relevant Markets and Principles, 98/C 262/02, O.J. C $265 / 2$.

${ }^{59}$ Decision of the Turkish Competition Board dated 6.8.2009 and numbered 09-35/877-206.
} 
these decisions, the Turkish Competition Board developed and applied consistent legal standards for a successful refusal-to-deal case. In the leading case, the Roaming ${ }^{60}$ the Turkish Competition Board held that refusal to deal will be regarded abusive provided that five conditions are met. These conditions are as follows: access to facility by the undertakings competing in the relevant market should be indispensable, and it should be impossible to supply the product or service without access to the network; there should be sufficient capacity to meet demand; the undertaking controlling the essential facility should deny the access to the facility and hinder the supply of a new substitute product or a service; the undertaking demanding access should be ready to pay a reasonable and nondiscriminatory price for the access; there should not be an objective justification for refusal. The Turkish Competition Board also explained what it meant by the first condition and, among other things, emphasized the importance of the nonduplicative feature of the facility. In the case at hand, building infrastructure for mobile communication was not feasable. Board had no difficulty in labeling the service as essential and nonduplicative.

Although quite common in the Turkish retail sector, exclusive agreements and practices have been occasionally analyzed under Article 6. There are only few infringements on this matter, and in the leading case, Karbogaz, the Turkish Competition Board explicitly stated that the exclusive contracts amounted to foreclosure of the market and therefore were abusive. ${ }^{61}$ Karbogaz was a dominant undertaking in the liquid carbon dioxide market, and in response to the prospect of the entry of a competitor, the Barit, it extended the duration of its 1-year exclusive supply contracts with major buyers (the Coca Cola Co., Pepsi Co., etc.) to 5 years. This policy was apparently aimed at the rival, and the purpose was to exclude the latter from the market. Upon a complaint by the rival, the Turkish Competition Board after analyzing the facts of the cases determined that even though the customers agreed with the extension of the contracts, there was no business purpose other than excluding the rival. The Turkish Competition Board did not discuss the efficiencies of the conduct and merely focused on the intention of the dominant undertaking. This is quite an unusual case, not only because very high penalties were imposed and the importance of intention was amplified but also because there was deviation from the general tendency of the Turkish Competition Board. When we look at the legal policy toward vertical exclusive agreements concluded by dominant undertakings, it is generally the case that the Turkish Competition Board has tended to base its analysis on Article 4 and has refrained from imposing fines. ${ }^{62}$ Since those agreements were covered by the Block Exemption Communiqué, withdrawal of the Block Exemption was deemed sufficient.

\footnotetext{
${ }^{60}$ Decision of the Turkish Competition Board dated 9.6.2003 and numbered 04-40/432-186.

${ }^{61}$ Decision of the Turkish Competition Board dated 23.8.2002 and numbered 02-49/634-257.

${ }^{62}$ See for example the Decision of the Turkish Competition Board dated 4.5.2004 and numbered 04-32/377-95; the Decision of the Turkish Competition Board dated 22.4.2005 and numbered 05-27/ 317-80; Decision of the Turkish Competition Board dated 10.9.2007 and numbered 07-70/ 864-327.
} 


\section{Concentrations}

\section{The Concept of Concentration}

For a transaction to fall within the scope of the Turkish merger control regime, it should qualify as a concentration. And, parallel to the EU merger regime if there is no change of control on a lasting basis according to Article 5 (1) of the recently enacted Merger Communiqué No. 2010/4 (Merger Communiqué or recently enacted Merger Communiqué), mergers or acquisitions are not assessed as concentrations.

The control of a firm or entity may be acquired by a single undertaking, leading to sole control, or jointly by two or more undertakings, leading to joint control. An acquisition of sole control would mean that there is a concentration in the form of a merger, while an acquisition of joint control means that the concentration is in the form of a joint venture. A concentration will also arise if there is a change from sole control to joint control or from joint control to sole control, including where this is a return to an earlier situation. Transactions in which there is a change in the structure of joint control (such as an increase in the number of shareholders exercising joint control) are also considered as a concentration.

Article 7 of the Antitrust Act has counted some means of transfer of control for acquisitions. Moreover, as in the definition of undertaking, the legal basis of the change of control is not important as competition law is concerned with the economic impact rather than the legal form. As a result, when there is no change of control, mergers or acquisitions are not assessed as concentrations in the Turkish Antitrust Law. The Turkish Competition Board has made this clear in its Uludag Erbag Decision ${ }^{63}$ as follows:

(...) when the essence of the acquisition transaction is dealt with, it is clear that both the partnership structures and The Turkish Competition Boards of management of the parties consist of the same persons, therefore, even though they are legally independent from each other these undertakings are dependent from the economic perspective and should be evaluated as a single economic unit.

While the Antitrust Act does not define the concept of control that is so vital for the merger regime, the Merger Communiqué provides the following definition in its Article 5(2):

For the purposes of this Communiqué, control may be acquired through rights, contracts or other instruments which, separately or together, allow de facto or de jure exercise of decisive influence over an undertaking. In particular, these instruments consist of ownership right or operating right over all or part of the assets of an undertaking, and those rights or contracts granting decisive influence over the structure or decisions of the bodies of an undertaking.

The essence of the definition lies in the words "decisive influence on an undertaking" as in the European Community Merger Regulation No 139/2004 since the

${ }^{63}$ Decision of Turkish Competition Board dated 03.03.1999 and numbered 99-12/93-35. 
means that bring control are not important in merger reviews. The existence of decisive influence cannot be established with certainty. The Merger Communiqué, thus, refers to the major forms of corporations.

The Merger Communiqué also provides the possibility for the consideration of occurrences with indirect control instead of direct control, in the third paragraph of Article 5(2), by stating that control can be acquired either by holders of rights or those "persons or undertakings who, while lacking such rights and powers, have de facto strength to exercise such rights." What matters here is where the decisionmaking capacity and commercial matters lies.

Mergers and acquisitions. In the Turkish Antitrust Law, the definition of concentration can be simplified to mean an act by an undertaking to take over exclusive or joint control of another undertaking. The defining characteristic of these operations is the requirement of a permanent or lasting change in the control structures of the undertakings resulting from the concentration process. In this sense, it is possible to classify two types of concentration: (a) the merger of two or more previously independent undertakings or (b) the acquisition of direct or indirect control of the whole or part of one or more other undertakings by one or more undertakings (or one or more persons already controlling at least one undertaking), whether by purchase of securities or assets, by contract, or by any other means. In the latter case, the legal personality of the acquired enterprise is terminated.

Joint ventures. Even if it is not a "merger" within the narrow meaning of the concept, the assembly of activities of undertakings under a single economic unit is also considered as a merger. This situation is generated particularly when two or more undertakings create a joint economic unit - a joint venture while maintaining their economic freedom and their seperate legal entities.

Joint ventures create further difficulty in merger control, since they are deemed to be concentrations only when they are autonomous. Such autonomous joint ventures are called full-functional in merger terminology. To qualify as autonomous, a joint venture should have the capacity to carry out all its functions by itself. These functions include, but are not limited to, management, production, and sales.

As a benchmark, a joint venture is expected to fulfill all the functions of a competing undertaking carried out in the relevant market. Thus, joint ventures that are formed for the purpose of outsourcing some of the tasks of the parent companies do not qualify as full-functional. If a joint venture is not full-functional, its anticompetitive effects, if there are any, can be examined under Article 4 of the Antitrust Act, which prohibits anticompetitive agreements.

Exceptions. The Merger Communiqué enumerates cases that are not considered as mergers or an acquisitions; thus, it is not required to obtain the authorization of the Turkish Competition Board for such mergers and acquisitions. The first exception is applied to undertakings whose ordinary activities are to transact with securities for their own account or for the account of others, temporarily hold the securities acquired with a view to reselling them, provided that the voting rights arising from 
such securities are not exercised by them in such a way that the competition policies of the undertaking issuing the securities are affected.

Another exception arises where the acquisition is carried out by a public institution and an organization with the aim or reason of liquidation, winding up, insolvency, cessation of payments, composition, and privatization or by a similar reason, and as required by law. The exemption also applies to the cases provided that they take place via inheritance.

Thresholds for notification of mergers. According to Article 7(1) of the Merger Communiqué, a merger must be notified and clearance must be obtained in the event of the following:

- Total turnovers of the transaction parties in Turkey exceed one hundred million TL, and turnovers of at least two of the transaction parties in Turkey each exceed thirty million TL, or

- Global turnover of one of the transaction parties exceed five hundred million TL, and at least one of the remaining transaction parties have a turnover in Turkey exceeding five million TL.

When looking at the high turnovers stated by the first threshold, it could be thought that the Authority opts to pay attention only to transactions which significantly affect Turkish markets. However, considering the second threshold that 500 million TL and 5 million TL are quite low thresholds for world-wide and Turkey turnovers, respectively, global transactions will be the main work load of the Authority. The Merger Communiqué thus adopts a dual or twin-track approach, that is, two different turnover criteria for determining the scope of merger control. Even if the thresholds listed above are exceeded, authorization of the Board shall not be required for transactions without any affected market according to Article 7 (2). However, this Article also states that this exception is not applied in cases of joint ventures. However, because the term "affected market" is brought into Turkish merger control regime by recently enacted Merger Communique, parties may not take the risk of being fined and notify their transactions in cases where it is not certain whether there is an affected market or not.

The calculation of turnover is a matter of accountancy, where, according to Article 8(6) of the Merger Communiqué, turnover "shall consist of the net sales generated as of the end of the financial year preceding the date of the notification, or, if this can not be calculated, of those generated as of the end of the financial year closest to the date of notification" excluding the sales of the relevant undertakings between themselves. If the concentration is the result of a partial acquisition, only the turnover of the transferred part is excluded from the turnover base.

\section{Merger Test: Creating or Strengthening Dominance and Thereby Lessening Competition}

The Turkish Competition Board assesses the competitive environment to be created after the transaction. This is an ex ante control mechanism. Once it is established that a concentration falls within the scope of Article 7 of the Antitrust Act, the 
Turkish Competition Board is required to carry out an examination that involves the execution of a dominance test and, if the outcome is positive, checking whether or not the concentration significantly decreases competition, i.e., applying what is called the SLC (Significant lessening of competition) test. Accordingly, the Antitrust Act defines the determination of the dominant position as a prerequisite for the assessment of whether the competition is significantly lessened through this dominant position. This approach is, a carbon copy of the previous EU legislation that implemented the European perception of merger control for 15 years.

The same goes also for the case of strengthening of a dominant position, a phenomenon that covers a wide range of transactions since it is possible for a dominant undertaking to acquire a small firm in the relevant market without altering the competitive conditions. ${ }^{64}$

The basic element of the dominance test is the market structure that can be determined by an examination of the market shares in the relevant market, the supply and demand elasticity of the relevant product, the market concentration (as usually measured by HHI Tests), the barriers to entry and exit, and also the developmental stage of the market. In other words, the Authority should determine the level of competitiveness in the relevant market and also study the factors that will have a bearing on the actual and potential competitive behavior of the concentration including the efficiencies. ${ }^{65}$

Although competition authorities of the US and EU adopted "competition test" (also called as SLC test) in assessing the merger cases, The Turkish Competition Board has not changed its old style "dominance test" yet. As such a change requires amendment in the Turkish Antitrust Law, recently enacted Merger Communiqué also follows the dominance test.

On the other hand, the Antitrust Act defines dominant position as the power of one or more undertakings to determine economic parameters by acting independently of their competitors and customers. Together with the provisions of the Article 6, it is clear that the Antitrust Act refers to cases where more than one undertaking may be in abusive conduct through the market power they hold which may classify both undertakings as being collectively in dominant position. Accordingly, the collective dominance is included in the definition of dominant position. Therefore, since mergers that create dominant position are prohibited, this prohibition should normally be expected to prohibit the cases of collective dominance as well. Although the Turkish Competition Board seems to depend on this approach implicitly when blocking mergers that cannot pass the SLC test at the background, the Appeal Court rejected the Turkish Competition Board's decisions

\footnotetext{
${ }^{64}$ Decision of Turkish Competition Board dated 02.05.2000 and numbered 00-16/160-82 (Cisco/ IBM) in which Cisco is market leader in switch market in terms of market shares and the transaction is found not to strengthen dominant position. See also Decision of Turkish Competition Board dated 10.02.2000 and numbered 00-6/51-23.

${ }^{65}$ According to the OECD this policy is an application of the standard multifactor analysis to concentrations. (OECD 2002), (OECD 2005).
} 
based on this approach in 2005. These are Ladik Cement ${ }^{66}$ and Şanliurfa Cement ${ }^{67}$ decisions, and they were the first prohibition decisions on collective dominance. The focus point was the questioned ability of the Turkish regime to prohibit a transaction where there is no creation of a single dominance but a collective dominance.

Ladik Cement decision has been brought to appeal before the Council of State, and it has been granted a stay of execution ${ }^{68}$ on the grounds that the Turkish merger control regime cannot prohibit a transaction that leads to collective dominance but the creation of single dominant position. Nevertheless, the controversy whether the Turkish merger regime allows the prohibition of a transaction leading to collective dominance has not been finalized as the plaintiff has withdrawn the case and the High Council of State has not reached its final judgment.

Recent decisions demonstrate that the Turkish Competition Board follows its approach that the concept of collective dominance is subject to evaluation within Article 7 of the Antitrust Act and the Merger Communiqué. In one of these decisions concerning the acquisition of Lipman Electronics by Verifone Inc ${ }^{69}$ the Turkish Competition Board ruled that Verifone does not hold a dominant position in postmerger POS devices market due to the strong presence of Ingenico, even though Verifone has a market share of over 50\%. However, the Turkish Competition Board stated that due to the oligopolistic and concentrated market structure, the transaction concerned has to be analyzed within the concept of collective dominance likely to be created by Verifone and Ingenico. It pointed out the following facts:

(a) POS devices market is a constantly growing, technology-based market and is prevailed by buyer power as the demand varies according to the the needs of customers.

(b) Nontransparency in the market arises from the sealed-bid tender processes enforced by the buyer banks of POS devices.

(c) Import facilities and tendency of buyer banks to work with more than one supplier make the coordination between competitors difficult.

Therefore, the Turkish Competition Board concluded that collective dominance cannot be created in such market conditions.

\section{Procedural Issues}

(a) Is the Final Agreement Between the Parties Required for the Assessment?

To start assessing a transaction, Article 7 of the Antitrust Act practice appraises the final consent of the parties for a proposed transaction as a prerequisite for the

\footnotetext{
${ }^{66}$ Decision of Turkish Competition Board dated 20.12.2005 and numbered 05-86/1188-340 dated 20.12.2005.

${ }^{67}$ Decision of Turkish Competition Board dated 20.12.2005 and numbered 05-86/1191-343.

${ }^{68}$ Decision of 13th Chamber of High State Council No. 2005/10038.

${ }^{69}$ Decision of Turkish Competition Board dated 13.04.2009 and numbered 09-14/300-73.
} 
initiation of competitive assessment. This mutual consent is usually present via a Sale Purchase Agreement, Memorandum of Understanding, binding offers signed by the parties. However, the established enforcement of the Turkish Competition Board demonstrates that it also evaluates and clears transactions that are notified with framework agreements or binding consensus of the parties with no final agreements. This may show that the Turkish Competition Board also follows the practice of the Commission in cases where the parties present their binding consent for the realization of the proposed transaction. It has to be emphasized that the Notification Form of the recently enacted M\&A Communiqué indicates that the final agreement between the parties is not required for the assessment of the Competition Authority since it demands the copy of final or draft agreement.

Even though the recently enacted Merger Communiqué remain silent on the issue, the Turkish Competition Board, in its decision dated 06.01.2010, numbered 10-01/13-8, also cleared the hostile takeover (Gürtler and Kräkel 2009, pp. 3-4) of Cadbury by Kraft Foods. In this case, the Turkish Competition Board accepted the notification made right after the public announcement of intention to make an offer in accordance with EU enforcement. However, it obliged Kraft to submit the final offer to the Turkish Competition Board.

(b) What Is the Time Table for the Clearance?

Preliminary Investigation (Phase I) As long as the transaction concerned does not pose a competitive concern, the Turkish Competition Board has to decide on a concentration transaction notified to it in 15 days starting from the date of receiving the notification file completely and accurately. However, the Turkish Competition Board is entitled to ask for additional information and documents which resets the 15 days.

Accordingly, a time table of 15 days for the first evaluation, 15 days for the submission of a possible additional information requested by the Turkish Competition Board, 15 days for reevaluation, 10 days for its decision, plus 10 days for notification of short decision is needed. So, if there is no unforeseen situation to clear the transaction, a maximum of 65 days is needed.

Final Investigation (Phase II) If the Turkish Competition Board decides to deal with the transaction under final investigation after Phase I procedure due to the competitive concerns, it is obliged to duly notify the parties, with its preliminary objection letter, that the merger or acquisition transaction is suspended and cannot be put into practice until the final decision, together with other measures deemed necessary by it. During this final investigation period, the Turkish Competition Board has 6 months to grant a final decision. If deemed necessary, this period may be extended once by up to 6 months by the Board.

(c) Does Failure of Notification/Closing Before Authorization Require Fines?

Where a merger and acquisition transaction whose notification to the Turkish Competition Board is compulsory is not notified to the Turkish Competition Board, the Board shall deal with the merger or acquisition under examination on its own initiative. As a result of this examination, the Board either authorizes or rejects the 
completion of the transaction; both undertakings in a merger or the purchaser in an acquisition are imposed fines up to $0.1 \%$ of the turnover of the undertakings concerned due to failure to notify. Aside from this administrative penalty, transactions leading to concentration are void.

If the Turkish Competition Board establishes that the transaction shall be prohibited, it terminates the transaction together with fines up to $10 \%$ and removes all de facto legal consequences of every action that has been taken.

\subsection{Consequences of Violations and Enforcement Institutions}

\subsubsection{Administrative Enforcement}

The Turkish Competition Board is the only administrative institution legally authorized to implement the Antitrust Act. As an independent regulatory agency, the Turkish Competition Board has the power to impose administrative sanctions under following articles:

- Article 10 - Notification of Mergers and Acquisitions to the Turkish Competition Board

- Article 13 - Revocation of Exemption and Negative Clearance Decisions

- Article 16 - Administrative Fine

- Article 17 - Proportional Administrative Fine

These provisions mainly set forth an enforcement system for the Turkish Competition Board to take administrative decisions and impose administrative fines against anticompetitive conduct.

In this section of our study, we start our analysis of consequences of violations and enforcement institutions with the Turkish Competition Board and its sanctions. Later on, we cover civil enforcement.

\subsubsection{The Turkish Competition Board}

Formation and Composition

The Turkish Competition Board is actually composed of the Turkish Competition Authority and its decision making body, the Competition Board. The Turkish Competition Board commenced its function 3 years after the enactment of the Antitrust Act in 1994. The Turkish Competition Board is headquartered in Ankara but has only a liaison office in Istanbul.

The Turkish Competition Board is autonomous, and thus it is independent when discharging its duties. No organ, authority, or person may give commands and orders to influence the final decision of the Board. The Board's decisions can be considered as semijudicial decisions granted by an administrative agency. 
The Turkish Competition Board consists of the Board, the Office of the President, Main Service Units, Auxiliary Service Units, and Advisory Units of a total of seven members, including the Chairman and the Deputy Chairman. The Presidency is formed of the Chairman of the Turkish Competition Board/President of the Authority, Deputy Chairman/President, and Vice Presidents. The Chairman is the highest ranking official of the Authority and is responsible for the overall management and representation.

The Main Service Units carry out the cases by competition experts and assistant experts. They are organized as departmental Head Offices, where each department is in charge of particular industries assigned to them.

The Turkish Competition Board gives decisions for each case reported by the Main Service Unit departments. According to Article 23 of the Antitrust Act, the Chairman and members shall be appointed from those who have had a 4-year higher education in one of the departments of law, economics, engineering, management, or finance. And finally The Competition Board has 7 members coming from different institutions. The selection process of the Board Members are outlined in the Article 22 as follow:

\footnotetext{
The Council of Ministers elects and appoints the members from among the two candidates apiece, to be nominated from inside or outside the following institutions for each vacant membership: two members from the Competition Board, one member from the Ministry of Industry and Trade, one member from the Ministry of State with which the Undersecretariat of State Planning Organization is affiliated, and one member apiece from the Supreme Court of Appeal, Council of State, and Turkish Union of Chambers and Commodity Exchanges.

The Council of Ministers shall commission one of the three candidates to be nominated by the Board as the President/Chairman. The Deputy President/Chairman is elected by the members of the Board.
}

\section{Investigative Powers}

In accordance with the Antitrust Act, an investigation may be commenced on a complaint, information or a notification, or the Authority may initiate the procedure ex officio. The investigation shall be concluded within 6 months, and where it is deemed necessary, the Turkish Competition Board may grant an additional period of 6 months only once. In Turkey, the Turkish Competition Board is competent with respect to the investigative measures including "Request for Information" and "On-the-Spot Inspection."

First, request for information is cited in Article 14 of the Antitrust Act as follows:

In carrying out the duties assigned to it by this Act, the Board may request any information it deems necessary from all public institutions and organizations, undertakings, and associations of undertakings.

Officials of these authorities, undertakings, and associations of undertakings are obliged to provide the requested information within the period to be determined by The Board. 
Accordingly, the article states that the Turkish Competition Board may be in need of detailed information to perform its duties. It shall obtain such information primarily from the concerned undertakings and associations of undertakings. In addition to this, it might need to obtain some information from several public organizations and private undertakings. Organizations other than the concerned parties may not deny the request of the Turkish Competition Board for information and document, either. ${ }^{70}$

But main flow of evidence comes from another mechanism, which is outlined in Article 15 of the Antitrust Act. This article sets forth the specifics of the on-the-spot inspection:

In carrying out the duties assigned to it by this Act, the Board may perform examinations at undertakings and associations of undertakings in cases it deems necessary. To this end, it is entitled to:

(a) Examine the books, any paperwork and documents of undertakings and associations of undertakings, and take their copies if needed

(b) Request written or oral statement on particular issues

(c) Perform examinations on the spot with regard to any assets of undertakings

Examination is performed by experts employed at the disposal of the Board. While going for an examination, experts carry with them an authorization certificate showing the subject matter and purpose of the examination, and that an administrative fine shall be imposed should incorrect information be provided. Those concerned are obliged with providing the copies of information, documents, books and other instruments requested. In case an on-the-spot inspection is hindered or likely to be hindered, the on-the-spot inspection is performed with the decision of a criminal magistrate.

Both of the articles involve the terms of "in carrying out the duties assigned to it by this Act"; as it is seen, the Turkish Competition Board's discretion on using the investigative powers is defined very widely. Although the inspection does not cover "searching," the authorization to search is used in practice. "The books, any paperwork and documents" expressions stated in the Antitrust Act may stand for "books and other business records" in EU legislation (Yolcu 2003, pp.49-50). However, differently from search, any power to use force or search of the person is not within the authorities of the Turkish Competition Board. In this framework, inspection can be performed on any kind of assets of an undertaking where it operates in terms of commercial activities (rooms, warehouses, garages, vehicles of buildings, safes, cabinets, drawers, bags located in rooms; computers, CDs, floppy disks, cassettes involving audio and image records, etc.) (The Seminar 2005). Finally, evidence not falling under the scope of the authorization allowing the inspection may be used as evidence in another case (ICN 2009).

\footnotetext{
${ }^{70}$ Grounds for the Article 14 of the Antitrust Act.
} 


\subsubsection{Administrative Fines}

The Antitrust Act foresees a strict investigation procedure to impose fine on undertakings up to $10 \%$ of the annual gross revenue. Article 16 and article 17 set forth the conditions for imposing fines.

Article 16 states the authorization to impose fines for the following cases: (a) false or misleading information or documents is provided in exemption and negative clearance applications and in authorization applications for mergers and acquisitions, (b) mergers and acquisitions that are subject to authorization are realized without the authorization of the Turkish Competition Board, (c) in implementation of Articles 14 and 15 of the Antitrust Act, incomplete, false, or misleading information or document is provided, or information or document is not provided within the determined duration or at all, and (d) on-the-spot inspection is hindered or complicated. For instance, the Turkish Competition Board has imposed a 11200 TL fine on Reysaş on the grounds that on-the-spot inspection was hindered and complicated. ${ }^{71}$

Provided that penalties mentioned in Article 16 paragraph 1 are reserved, according to Article 17, the Turkish Competition Board shall, for each day, impose on undertakings and associations of undertakings an administrative fine by five in ten thousand of annual gross revenues in the event that (a) obligations introduced or commitments made by a final decision or interim measure decision are not complied with, (b) on-the-spot inspection is hindered or complicated, (c) in implementation of Articles 14 and 15 of the Antitrust Act, information or document requested is not provided within the duration determined. Besides, Article 16 also specifies that

issues taken into consideration in fixing administrative fines to be imposed pursuant to this article, terms for immunity from or reduction of fines in case of cooperation, and procedures and principles in relation to cooperation shall be determined by communiqués to be issued by the Board.

From this point of view, the Turkish Competition Board introduced "Regulation on Active Cooperation for Detecting Cartels" and "Regulation on Fines to Apply in Cases of Agreements, Concerted Practices and Decisions Limiting Competition, and Abuse of Dominant Position" in 2009. Under the new regime, the fines begin from (a) $2-4 \%$, for cartels and (b) $0.5-3 \%$, for abuse of dominance. The Turkish Competition Board will apply aggravating and extenuating factors to the abovestated base fines.

As a result of these two regulations aiming at increasing transparency, objectivity, and consistency and ensuring deterrence of anticompetitive practices, the fines applied in this legal framework increased significantly in 2009 (Directorate for Financial and Enterprise Affairs Competition Committee 2010). The highest fine on a single undertaking up to now is TL $36,072,230$, which was imposed on Turkcell. ${ }^{72}$

\footnotetext{
${ }^{71}$ Decision of Turkish Competition Board dated 11.11.2009 and numbered 09-54/1320-M.

${ }^{72}$ Mobile Marketing Decision dated 23.12.2009 and numbered 09-60/1490-379.
} 


\subsubsection{Administrative Injunctions}

In general, the Turkish Competition Board's tendency is to give injunctions to the relevant parties involved in a competition infringement. For instance, in its decision regarding Audit Bureau of Circulation ( $\mathrm{ABC}$ )'s discriminatory anticompetitive practices against a newspaper (Zaman), the Board decided that an investigation was not required to be opened in accordance with Article 41 of the Antitrust Act. But the Turkish Competition Board concluded that ABC's practices resulted in harming the market mechanism and invalidated its inspection results. In the decision, the Turkish Competition Board rejected the inspection results provided by $\mathrm{ABC}$ and gave an additional 90 days period to set new standards that may enable all media and press institutions to be represented equally and prevent any privileges to newspapers working on a subscription basis, and it withdrew the exemption granted to ABC Corporation Agreement. ${ }^{73}$

\subsubsection{Interim Measures}

In the case of urgency due to the risk of serious and irreparable damage to competition, the Turkish Competition Board may order interim measures prior to taking a decision on the merits of the case. Article 9 of the Antitrust Act states the following:

where the occurrence of serious and irreparable damages is likely until the final decision, the Board may take interim measures, which have a nature of maintaining the situation before the infringement and which shall not exceed the scope of the final decision.

The article provides the methods that the Turkish Competition Board shall follow, in case of infringements of the Articles 4, 6, and 7, to terminate the infringements and states that the Turkish Competition Board can take interim measures if there are strong signs that show that serious and irreparable damages may occur before the final decision is made. ${ }^{74}$ For instance, the Turkish Competition Board, in TTNET Decision, ${ }^{75}$ had taken an interim measure to terminate price squeeze practices, before the final decision was given. Türk Telekom and TTNET terminated the relevant practices in compliance with the interim measure. ${ }^{76}$

\subsubsection{Civil Enforcement}

The Antitrust Act adopted a dual enforcement system. Besides the Turkish Competition Board, the civil courts also have the jurisdiction to apply the Turkish Antitrust Law. To this end, Articles 56-59 set out specific provisions about the civil

\footnotetext{
${ }^{73}$ Decision of Turkish Competition Board dated 24.4.2007 and numbered 07-34/347-127.

${ }^{74}$ Grounds for the Article 9 of the Antitrust Act. No. 4054.

${ }^{75}$ Decision of Turkish Competition Board dated 19.11.2008 and numbered 08-65/1055-411.

${ }^{76}$ Decision of Turkish Competition Board dated 11.7.2007 and numbered 07-59/676-235.
} 
law consequences of antitrust violations. According to these provisions, civil enforcement is based on two pillars: "nullity" and "tortious liability." It is clear that by drafting specific provisions, the lawmaker intended to increase the effectiveness of the enforcement of the Antitrust Act. However, currently, the civil enforcement seems underdeveloped, and reconsideration of the relevant provisions of the Antitrust Act might be necessary to increase the deterrence of the civil enforcement. ${ }^{77}$ Below, the application of civil law consequences is explained in detail.

\subsubsection{Nullity}

According to Article 56 of the Antitrust Act, any agreement contrary to Article 4 of the Antitrust Act is void and unenforceable before the courts. The provision does not set out the nature of the nullity. However, as Article 4 is a mandatory provision, which aims to protect public interest, its violation should lead to ab initio and automatic nullity. Nullity occurs without a need for any proceeding or legal action; the court will take nullity into account on its own initiative. However, nullity is not absolute because if Article 5 applies to the case, then the agreement restricting the competition becomes lawful. So, the probability of application of Article 5 transforms this nullity into a "provisional" one. Absolute nullity exists only if the conditions of Article 5 are not satisfied (Sanl1 2007, p.18; Gürzumar 2002, p.53; Özdemir 2002, p. 177; (Aslan 2007, p. 770). ${ }^{78}$ Both types of exemptions validate the agreement restricting competition; however, in the case of individual exemption, a decision of the Turkish Competition Board is required. This complicates the application of nullity by courts as the Turkish Competition Board has monopoly over granting an exemption decision. This is one of the factors that impede the effectiveness of civil enforcement system.

The Antitrust Act does not contain any specific rule on the nullity of agreements contrary to Article 6, but given the wording and the purpose of Article 6, legal transactions contrary to that article should lead to some sort of nullity. As there is no exemption provision for Article 6, one may first think that absolute nullity applies in this case. However, considering the types of abusive behavior, this does not seem like an appropriate solution. In some cases, it is highly likely that invalidity of an agreement or a decision would be contrary to the end that the competition law seeks to achieve. For instance, applying absolute nullity in the case of predatory pricing will lead to absurd results. First, voidness of legal transactions with low prices will victimize third parties who are completely alien to the conflict, and punishing them does not serve a meaningful end. Second, many transactions will

\footnotetext{
${ }^{77}$ The Draft of Proposed Law has numerous new provisions on the civil law consequences of the Antitrust Act. For a detailed analysis of this matter, see (Sanl1 2007).

${ }^{78}$ However, there are conflicting views about the nature of the nullity. See for example (Aksoy 2004, p. 45).
} 
become void, and this will impose huge transaction costs on the legal system and seriously impair the principle of legal certainty. So, applying absolute nullity across the board is not a good solution. However, in some cases, such as exclusive dealing, invalidating contracts appears to be a fitting sanction. In those cases, by invalidating these contracts, parties will be free to make a contract with third parties, and the foreclosure effect will be diminished. Thus, with respect to Article 6, it seems that nullity should be applied based upon the discretion of the judge analyzing the case (Sanl1 2007, p. 16; also see Aslan 2007, p.783). This type of nullity exists in Turkish private law and is named "discretionary nullity."

The Antitrust Act does not have any explicit provision with respect to the civil law consequences of the mergers and acquisitions that are contrary to Article 7. However, considering the nature of Article 7 and some other rules (Article 10, 11) in the Antitrust Act, there is no doubt that the legal sanction of Article 7 is "absolute nullity"(Sanl1 2000a, p.445). Here, nullity applies as a consequence of not only substantial infringements but also procedural violation. According to the second paragraph of Article 7, "The Board shall declare, via communiqués to be issued by it, the types of mergers and acquisitions which have to be notified to The Turkish Competition Board and for which permission has to be obtained, in order them to become legally valid." The Turkish Competition Board has issued the communiqué, and this rule is repeated in Article 1 of that legal document. So, mergers and acquisitions falling within the Communiqué are not valid, until an explicit or implicit decision is granted by the Turkish Competition Board. In that time frame, the nullity of transactions is provisional in nature (Sanl1 2000a, p.446; Aksoy 2004, p. 41).

\subsubsection{Damages}

The main component of the civil enforcement is obviously tort liability of antitrust offenders. ${ }^{79}$ The Antitrust Act explicitly grants rights to third parties to claim damages and provides some unique provisions with an aim to increase the effectiveness of the civil enforcement. According to Article 57, "Anyone who prevents, distorts, or restricts competition via practices, decisions, contracts, or agreements contrary to this Act, or abuses his dominant position in a particular market for goods or services, is obliged to compensate for any damages of the injured. If the damage has resulted from the behavior of more than one people, they are responsible for the damage jointly." From the wording of this rule, it appears that infringing Article 7 does not lead to a damage action. This proposition makes sense since concentrations are controlled ex ante and infringing Article 7 rarely causes any recoverable damage. So, it is possible to argue that losses resulting from infringement of Article 7 are not within the protective sphere of Article 7 (Sanlı 2003, pp. 230-231; Gürzumar

\footnotetext{
${ }^{79}$ For a detailed analysis of tort liability in Turkish Antitrust Law see (Sanl1 2003).
} 
2005, pp. 150-151; İnan 2002, pp.609-610). However, this matter is controversial in Turkish law, and there are opposite views (Aslan 2007, p.784; Güven 2005, p. 515; Topçuoğlu 2001, p. 310).

The first paragraph of Article 58 provides a provision on the calculation of damages. According to the article: "Those who suffer as a result of the prevention, distortion, or restriction of competition may claim as a damage the difference between the cost they paid and the cost they would have paid if competition had not been limited. Competing undertakings affected by the limitation of competition may request that all of their damages are compensated by the undertaking or undertakings which limited competition. In determining the damage, all profits expected to be gained by the injured undertakings are calculated by taking into account the balance sheets of the previous years as well." There are two things worth mentioning about this article. The first is that it does not provide a unique principle about calculating damages. Should there be no explicit provision, general principles of damage calculation would govern the matter in the same way. Second, the article expresses that the competitors have a standing, but it does not limit the scope of litigants. Therefore, in the light of expansive wording, it seems that both consumer and nonrival undertakings have a standing.

The second paragraph of Article 58 sets out an interesting and problematical provision. According to the article, "If the resulting damage arises from an agreement or decision of the parties, or from cases involving gross negligence of them, the judge may, upon the request of the injured, award compensation by threefold of the material damage incurred or of the profits gained or likely to be gained by those who caused the damage." This is a unique provision for Turkish law as it enables the injured parties to claim three times their damages. The general principle in Turkish private law is that the compensation is limited to the amount of damages. So, by allowing victims to ask for three times their damages, the compensatory nature of the damage action becomes punitive in the Turkish Antitrust Law. The rationale of this rule, which probably was inspired by the Clayton Act of the USA, is to facilitate private actions by creating financial incentives to antitrust victims (Sanlı 2003, p. 270; Gürzumar 2005, p. 169). Although currently there is not much private antitrust litigation, this rule, if correctly interpreted, will no doubt increase the enforcement of private competition law.

An important error in the wording of the provision is that, it mentions "agreement or decision" as if these concepts are related to the state of mind of an antitrust offender or faultiness. Such wording is interpreted theologically and understood as "intentional" (Sanl1 2003, p. 270; Aksoy 2004, p. 58). ${ }^{80}$ So, the judge may award three times compensation, if the resulting damage arises from intentional or gross negligent behavior of the antitrust offenders. It should also be mentioned that, unlike the US practice, the judge may, based upon his/her discretion, award one or twofold damages (Sanlı 2003, p. 271). The factors affecting discretion will be determined according to the general principles in Turkish private law (Articles 43-44 of the Code of Obligation).

\footnotetext{
${ }^{80}$ That wording has been corrected in the Draft Law see (Sanlı 2007, pp.47-48).
} 
Article 59 provides a provision that shifts the burden of proof to the defendant in cartel cases. According to the article: "Should the injured submit to the jurisdictional bodies proofs such as, particularly, actual partitioning of markets, stability observed in the market price for quite a long time, the price increase within close intervals by the undertakings operating in the market, which give the impression of the existence of an agreement, or the distortion of competition in the market, then the burden of proof is for the defendants that the undertakings are not engaged in concerted practice. The existence of agreements, decisions and practices limiting competition may be proved by any kind of evidence." This rule is in line with presumption of concerted practice, which is governed by Article 4/3. So, the Antitrust Act seeks to ease the burden of proof not only for the Turkish Competition Board but also for private plaintiffs.

The principles regarding antitrust damages in the Antitrust Act are limited to these articles. So, other conditions of tort liability are governed by general principles of private law. In this regard, apart from sustaining damages and illegal behavior, fault and causality will be required to recover damages. Issues regarding limitation, competent courts, and evidence are also regulated under general principles of private and procedural law. However, there are certain unique matters of competition law litigation for which general principles of Turkish law may not produce adequate solutions: for instance, issue of "passing-on defence." According to this defense rule, which was borne in the US litigation practice, the defendant argues that the plaintiff did not sustain whole or part of the damage (price increase) because by reflecting the price increase to its customers, the burden of price increase is dispersed in the different levels of the economic chain. So, to recover damages, the plaintiff should prove that as a customer, it not only paid a monopoly price, but also absorbed the premium and did not pass on the premium to its customers. The Turkish law seems silent on this issue, and it would be useful to unambiguously address this matter in the Antitrust Act (Sanl1 2007, p. 68).

Similarly, it is not clear whether the customers in downstream markets, who may sustain damages as a result of the passing on of the price premium, have a standing to sue for their damages. In the US litigation, the Supreme Court solved the problem by denying the indirect purchaser's claims in a famous case of Illinois Brick Co. v. Illinois, ${ }^{81}$ and the principle is known as "Illinois Brick rule." Despite the fact that indirect purchasers might have been genuinely injured by the antitrust violation, it seems likely that the "relational economic loss rule" of Turkish private law would bar their claim. Besides, allowing indirect buyers to sue for their damages would significantly burden the enforcement system. However, that matter is controversial (Sanlı 2003, p. 240; Topçuoğlu 2001, p. 303).

The Antitrust Act does not contain any provision regarding the relation between the courts and the Turkish Competition Board either. It is unambiguous that both institutions have jurisdiction regarding the application of the Antitrust Act. As a general matter, when that is the case, there is a risk of contradictory judgments and

${ }^{81}$ Illinois Brick Co. v. Illinois, 431 U.S. 720 (1977). 
it seems difficult to deal with this risk under Turkish law. Similar to this risk, the legal effect of an earlier decision granted by an institution, i.e., the Turkish Competition Board, on the other institution's decision-making process, i.e., of courts, is not clear. Unfortunately, the recent judgments of the Court of Appeals on the matter further complicate the issue. Accordingly, in the majority of the cases decided by the Court of Appeals, the Turkish Competition Board has the sole authority on the determination of infringement, and the courts have a jurisdiction only after the Turkish Competition Board has given a verdict on the conflict. ${ }^{82}$ Should there be no verdict of the Turkish Competition Board, the courts have to refer the matter to the Turkish Competition Board and postpone the judgment until the Board makes a decision. This view apparently diminishes the effectiveness of private enforcement and frustrates the purpose of the dual enforcement system. However, in a minority of decisions, the Court of Appeals accepted the view that courts can decide on the infringement of the Antitrust Act without referring the case to the Turkish Competition Board. ${ }^{83}$ This is a crucial matter for efficient operation of the system, and especially for follow-on cases, we are of the opinion that there should be clarity about legal effects. ${ }^{84}$

\subsection{Conclusion}

Turkish Antitrust Act, being a relatively new law, not surprisingly various problems occurred during its 13 years of enforcement. For instance, almost all of the final decisions of the Turkish Competition Board have been quashed by the Council of the State on procedural grounds, and therefore, hundreds of repetitive decisions have been taken by the Turkish Competition Board. This legal setback not only diminished the effectiveness of the competition law but also created a lot of burden on the Turkish Competition Board, and for a long period, a fraction of its resources has been allocated to deal with this problem. Thankfully, the Turkish Competition Board reconsidered its methods of decision making and issued several regulations, which basically aim to increase the quality of the internal legal processes.

Another drawback that we notice when we look back is the tolerant and sometimes inconsistent enforcement policy pursued by the Turkish Competition Board. Despite the fact that substantive law was very well developed during the 13 years

\footnotetext{
${ }^{82}$ The Court of Appeals, 19. HD 1.11.1999 Date., File no: E 99/3350, K.99/6364; The Court of Appeals 19. HD 3.1.2003 Date., File no: E.2002/2827, K.2002/7580; The Court of Appeals 19 HD. 29.11.2002 Date. File no: 2002/2827 E. and 2002/7580 K.., The Court of Appeals 19. HD. 6.11.2006 date and File no 2006/2809 K., 2006/10346 E.

${ }^{83}$ The Court of Appeals 13. HD. 25.12.2002 date and file no: 2002/12626 E. 2002/14028; The Court of Appeals, 19. HD. 21.4.2005 date and file no: 2004/9634E. and 2005/4463 K.

${ }^{84}$ For a detailed examination of relations between courts and the Turkish Competition Authority, see (Sanlı 2003, pp. 255-265; also İnan 2002, pp. 590-628).
} 
of implementation, for some reason, the Turkish Competition Board followed a weak enforcement policy. We have observed this not only for vertical restraints and mergers but also for cartels. That attitude has been changing in a positive direction as well. In early 2009, the Turkish Competition Board has issued two important regulations that aim to increase the deterrence and to attain consistency in its enforcement policy. Application of the Fine Regulation increased the amount of fines substantially. This development together with the Leniency Regulation totally changed the enforcement policy toward cartels. It is also observed that the level of investigations has been increasing for the past 3 years, which should be considered as an improvement.

Finally, a few words should be expressed about the legislative endeavors of the Turkish Competition Board and the prospects of the competition law. As just mentioned, it is likely that more vigorous enforcement policy will be implemented, and thanks to new regulations about decision-making processes, the quality of decisions will be improved, which will in turn decrease the amount of reversal decisions of the State Council. It is also probable that the Turkish Competition Board will continue its efforts on legislative activities, which have been already very intensive in the past. There is a Draft of the Antitrust Act waiting in the legislative process, and should that be adopted by the Parliament, there will be major changes in competition law including exemption, mergers, and investigation methods. This law will also drastically alter and improve the current system. Another important development should be expected in the private enforcement system. The Draft already contains new provisions regarding the private law consequences of the competition law, which might enhance the effectiveness of the civil enforcement. Besides, the Turkish Competition Board has given many infringement decisions, and one should expect "follow-on cases" brought by antitrust victims.

\section{References}

Aksoy, N. (2004). Rekabetin Korunması Hakkında Kanun’a Aykırılığın Özel Hukuk Alanındaki Sonuçları. Ankara.

Aslan, Y. (2007). Rekabet Hukuku. Bursa.

Directorate for Financial and Enterprise Affairs Competition Committee. (2010). Annual Report on Competition Policy Developments in Turkey.

Erol, K. (2000). Rekabet Kurallarının Ülke Dışı Uygulanması. Rekabet Kurumu Yayını.

Gürtler, O., Kräkel, M. (2009). HostileTakeover and Costly Merger Control.

Gürzumar, O. B. (2002). 4054 Sayılı Rekabetin Korunması Hakkında Kanun'un 4. Maddesine Aykırı Sözleşmelerin Tabi Olduğu Geçersizlik Rejimi. Rekabet Dergisi, S.12, pp. 3-76.

Gürzumar, O. B. (2005). Özel Hukuk Açısından 4054 Sayılı Kanun. 4054 Sayılı Rekabetin Korunması Hakkında Kanun ve Bu Kanun'da Değişiklik Yapılmasına İlişsin Taslak, Sempozyum, 7-8 Ekim 2005; Banka ve Ticaret Hukuku Araştırma Enstitüsü Yayın No 426; Ankara, pp. 117-184.

Güven, P. (2005). Rekabet Hukuku. Ankara.

İnan, N. (2002). Rekabet Hukuku Uygulamasında Adliye Mahkemelerinin Rolü. Ankara Barosu Uluslar aras1 Hukuk Kurultay1, pp.590-628. 
International Competition Network (ICN). (2009). Anti-Cartel Enforcement Template. Subgroup 2: Enforcement Techniques: Turkey.

Jones, A., Sufrin, B. (2004). EC Competition Law: Text, Cases and Materials, New York: Oxford University Press.

Monti, M. (2003). The Relationship Between CAP and Competition Policy. Does EU Competition Law Apply to Agriculture? COGECA Conference Helsinki Fair Trade.

OECD. (2002). Competition Law and Policy in Turkey.

OECD. (2005). Competition Law and Policy in Turkey.

Özdemir, O. S. (2002). Sınai Haklara İlişkin Lisans Sözleşmeleri ve Rekabet Hukuku Düzenlemelerinin Lisans Sözleşmelerine Uygulanması. Istanbul.

Sanlı, K. C. (2000). Rekabetin Korunması Hakkındaki Kanun'da Öngörülen Yasaklayıcı Hükümler ve Bu Hükümlere Aykırı Sözleşme ve Teşebbüs Birliği Kararlarının Geçersizliği.

Sanlı, K. C. (2000b). Relabet Hukukunda Tekelci Fiyatlandırma, Perşembe Konferansları, S.10, Rekabet Kurumu Yayını Ankara, pp.75-165.

Sanlı, K. C. (2003). Rekabet Hukukunda Haksız Fiil Sorumluluğu. Rekabet Hukukunda Güncel Gelişmeler Sempozyumu I. Konferans Kitabı (editör Ayşe Odman Boztosun), Rekabet Kurumu Yayını, Ankara, pp. 211-277.

Sanlı, K. C. (2007). Rekabetin Koruması Hakkında Kanun Tasarısı Taslağı'nın Özel Hukuk Hükümlerinin Değerlendirilmesi, pp. 30-72.

Topçuoğlu, M. (2001). Rekabeti Kısıtlayan Teşebbüsler Arası İşbirliği Davranışları ve Hukuki Sonuçları. Ankara.

Yolcu, İ. (2003). Assessment of the Investigation Procedures in the Act No. 4054 on the Protection of Competition and the Procedural Problems Arising from their Implementation in Comparison with the EC Law. 